\title{
To Be or Not to Be: Environmental Factors that Drive Myelin Formation during Development and after CNS Trauma
}

\author{
Nicole Pukos ${ }^{1,2,+}$, Rim Yoseph ${ }^{1,2,+}$ (D) and Dana M. McTigue 2,3,*(D) \\ 1 Neuroscience Graduate Program, Ohio State University, Columbus, OH 43210, USA; \\ pukos.1@buckeyemail.osu.edu (N.P.); yoseph.5@buckeyemail.osu.edu (R.Y.) \\ 2 Center for Brain and Spinal Cord Repair, Ohio State University, Columbus, OH 43210, USA \\ 3 Department of Neuroscience, Ohio State University, Columbus, OH 43210, USA \\ * Correspondence: mctigue.2@osu.edu; Tel.: +1-614-292-5523 \\ + These authors contributed equally to this manuscript.
}

Received: 7 May 2018; Accepted: 4 June 2018; Published: 11 June 2018

\begin{abstract}
Oligodendrocytes are specialized glial cells that myelinate central nervous system (CNS) axons. Historically, it was believed that the primary role of myelin was to compactly ensheath axons, providing the insulation necessary for rapid signal conduction. However, mounting evidence demonstrates the dynamic importance of myelin and oligodendrocytes, including providing metabolic support to neurons and regulating axon protein distribution. As such, the development and maintenance of oligodendrocytes and myelin are integral to preserving CNS homeostasis and supporting proper functioning of widespread neural networks. Environmental signals are critical for proper oligodendrocyte lineage cell progression and their capacity to form functional compact myelin; these signals are markedly disturbed by injury to the CNS, which may compromise endogenous myelin repair capabilities. This review outlines some key environmental factors that drive myelin formation during development and compares that to the primary factors that define a CNS injury milieu. We aim to identify developmental factors disrupted after CNS trauma as well as pathogenic factors that negatively impact oligodendrocyte lineage cells, as these are potential therapeutic targets to promote myelin repair after injury or disease.
\end{abstract}

Keywords: development; spinal cord injury; myelination; growth factor; cytokine; oligodendrocyte progenitor cells

\section{Introduction}

The central nervous system (CNS) provides an excellent model to study cellular interactions because of the intimate association of its main parenchyma-neurons and glia. Neurons conduct action potentials and communicate to other neurons and cells throughout the body. Glia, representing the majority of the cells in the CNS, were originally referred to as helper cells, but studies have verified their importance in proper CNS functions, including communication between neurons. An essential component for rapid neuron signaling, especially for larger axons, is axon ensheathment by myelin. Oligodendrocytes (OLs) produce CNS myelin, which was first described by van Leeuwenhoek in 1717 [1]. Myelin does not just passively wrap axons, however. Extensive molecular interactions between OLs and axons regulate axon structure, including cytoskeletal maturation and restricting ion channels to nodal regions [2,3]. Evolutionarily, myelin first appeared when animals formed jaws and increased in physical size; myelin allowed increased axon conduction speed, which in turn allowed for faster escape from predators [4]. This huge evolutionary advantage separates vertebrates from invertebrates, who have supporting cells around axons rather than compact myelin [4]. 
Oligodendrocytes terminally differentiate from distinct cellular domains within the developing neural tube. As cells transition from an embryonic stem cell to oligodendrocyte progenitor cells (OPCs), OL lineage specific markers are upregulated; as cells continue to mature, they differentiate into OLs that engage axons and form compact myelin [5]. Interestingly, the adult CNS maintains a large population of OPCs throughout the white and gray matter whose OL progenitor role is retained (for recent review, see [6]). Indeed, the response of adult OPCs after experimental demyelination is well-documented and includes proliferation, migration into the demyelinated lesions and differentiation into remyelinating OLs [7,8]. However, their role in endogenous myelin repair after other types of CNS damage such as trauma is not fully understood. This is, in part, due to the complex biochemical cascades that are unique to the trauma milieu, which are initiated immediately after injury but then fluctuate over time. This review will begin by outlining some key factors in normal myelin development and then discuss how these and other factors affect the response of OPCs to CNS trauma.

\section{Development: OPC Migration, Proliferation, and Differentiation}

Gans and Northcutt theorized that vertebrates exist because of the neural crest, a source of diverse cell lineages derived from the embryonic ectoderm [9]. These multipotent neural stem cells give rise to OPCs, the majority of which arise from the motor neural progenitor (pMN) domain of ventral ventricular zone in the spinal cord, although $\approx 20 \%$ originate in the dorsal ventricular zone [10-13]. Both intraspinal progenitor populations have the same electrophysiological properties, but dorsal progenitors arise later and myelinate dorsal spinal tracts whereas ventral progenitors migrate dorsally and laterally to populate the entire white matter of the spinal cord; a similar wave of ventral to dorsal OPCs populate the brain developmentally [13-16]. During the first few postnatal weeks, a subset of OPCs extends branches to contact surrounding axons and terminally differentiate into mature OLs. Each developmental step is strictly regulated by a multitude of extracellular and intracellular signaling molecules that cooperate and coordinate to ensure proper CNS assembly (for recent review, see [5]).

\subsection{Migration}

Successful myelination of the CNS is contingent upon proper OPC migration. In the spinal cord, migration is strongly regulated by sonic hedgehog (Shh) and bone morphogenic protein (BMP). Sonic hedgehog is a ventral inductive signal secreted by the notochord that induces OPC specification in the ventral neural tube, whereas dorsal progenitors are Shh-independent and rely on local stimuli like BMP for induction [12,17-19]. Once formed, OPCs migrate in waves from the ventricular zone to distribute equally throughout the grey and white matter, with each cell occupying its own non-overlapping domain with neighboring OPCs [12,20,21]. For this to occur, OPCs need a mechanism to spatially locate neighboring OPCs. Indeed, dynamic filopodia from OPCS continuously surveil their environment to locate adjacent OPCs and guide cell trajectory [21]. In vivo imagining of OPCs in zebrafish shows OPCs exhibit contact-mediated inhibition in which they retract and change direction upon contacting filopodia from neighboring cells [21,22]. While all cellular signals causing retraction are not entirely known, Nogo-A is one factor thought to be involved in OPC spacing [23].

\subsubsection{Growth Factors}

Platelet-derived growth factor (PDGF) is secreted by astrocytes [24], which first form at embryonic day 16 in mice [25]. Similar to Sh, PDGF is secreted early during OPC migration and functions as a chemoattractant through activating the extracellular-regulated-kinase (ERK) signaling pathway [26]. Initially, PDGF acts a mobilizer to enhance cell mobility, and competes with Netrin-1, a laminin-like guidance molecule expressed in the floor plate [27]. Oligodendrocyte progenitor cells express Platelet-derived growth factor receptor alpha (PDGFR $\alpha$ ) and netrin receptors, allowing both ligands to act as migratory cues in which netrin opposes PDGF-induced migration [25,28-31]. As OPCs migrate to their final target, they encounter various extracellular matrix ligands to which they are responsive [32]. Of particular importance are integrins, cell surface receptors that facilitate 
bidirectional signaling between the intracellular and extracellular environment. PDGF binds to integrin $\alpha_{v} \beta_{3}$, which stimulates OPC migration and proliferation [33]. Despite its crucial role, however, PDGF does not act as solitary migratory factor but instead cooperates with other environmental cues for proper signaling.

Fibroblast growth factor 2 (FGF-2) is also produced by astrocytes [34] and stimulates OPC migration, although not as strongly as PDGF. For instance, transient exposure to FGF-2 has no effect on OPC migration, whereas OPCs show long-term migration when exposed to PDGF-A under the same conditions [26]. Treating cells with both growth factors leads to faster migration compared to either alone, and also converts progenitors from slowly to rapidly dividing cells [26,35-38]. Similar to PDGF-A, FGF-2 promotes OPC migration via the ERK1/2 signaling pathway after binding to its receptors FGFR1, which is necessary for FGF-2-induced migration [27,37,39,40]. Overall, FGF-2 is crucial for OPC migration, but the combinatory effects of PDGF and FGF-2 far surpass that of either factor alone, indicating proper OL development is contingent upon signaling from multiple factors.

\subsubsection{Chemokines}

Chemokines are secreted "chemotactic cytokines" best known for their role in regulating immune cell migration. Interestingly, chemokines in the $\mathrm{C}-\mathrm{X}-\mathrm{C}$ family also promote OPC proliferation and migration.

CXCL1 (also known as Gro- $\alpha$ ) is expressed by astrocytes and binds to CXCR2 on OPCs to inhibit PDGF-stimulated migration [41-44]. CXCL1 signals through CXCR2 and serves as a stop signal for developmental OPC migration [43,45]. The importance of CXCL1 for proper OPC distribution is seen when it is absent, which results in continued OPC migration to the pial surface with extensive OPC migration into the periphery [46]. Most OPC proliferation occurs in the white matter as PDGF and CXCL1 work synergistically to inhibit migration while simultaneously promoting proliferation [41]. Eliminating CXCR2 expression diminishes OPC proliferation and reduces OL numbers, thereby reducing myelination and overall white matter area $[43,45]$. These studies highlight the importance of CXCL1 in localizing cells to allow for proper patterning of the white matter and efficient myelination.

CXCL12, also known as stromal cell-derived factor 1, binds to its receptor CXCR4, a G-protein coupled receptor highly conserved in evolution. Detection of CXCL12 and its receptor expression begins around E7.5 in the ventral neural tube, and expands to various cell types including OLs and neurons as the CNS matures [46-48]. The diverse expression of CXCL12 is crucial for proper CNS development, as the knockout of its receptor is embryonic lethal due to complications in the immune and central nervous systems [49]. For OPCs, CXCL12 acts a chemoattractant that promotes migration, proliferation, and survival in the brain and spinal cord [50,51]. Oligodendrocyte progenitor cells in CXCR4-deficient mice fail to migrate dorsally from the ventral neural tube since they are unresponsive to CXCL12. CXCR4 expression peaks during OPC migration, then decreases as OPCs differentiate in OLs, indicating CXCL12 and its receptor are important during early CNS development [50]. Overall, chemokines regulate the outward migration of OPCs from the neural tube to allow for proper CNS patterning.

\subsection{Proliferation}

\subsubsection{Three Major Mitogens}

In addition to promoting OPC migration, PDGF also acts a mitogen and is crucial for glial progenitor cell survival $[24,29,52]$. However, unlike migration, PDGF proliferation is mediated by the phosphatidylinositol-3-kinase (PI3K)-Akt and Wnt- $\beta$-catenin signaling pathways instead of the ERK pathway [53]. Interestingly, a population of proliferating OPCs is maintained into adulthood in the CNS $[54,55]$. Since OPCs in culture do not mimic this proliferative response, it suggests the balance between OPC self-renewal and differentiation is regulated by intrinsic and extrinsic signaling 
molecules [56-58]. Indeed, OPCs supplemented with astrocytes or PDGF, in traditional and new culture assays, proliferate steadily for weeks [38,59-62]. Blocking PDGF in the developing optic nerve reduces proliferation by $70 \%$ and progenitors immediately differentiate into OLs [60], findings that were later confirmed in vivo $[25,29,63,64]$. Complete PDGFR $\alpha$ knockout mice die in utero due to complications in patterning and cell survival throughout the body [65]. However, PDGF-deficient mice survive into adulthood but present with fewer OPCs and OLs, with the largest loss in the spinal cord and cerebellum; as would be expected, PDGF over-expression results in hyper-proliferation of OPCs [66-68]. Together, these experiments illustrate that PDGF and its receptor are important for controlling the timing and rate of proliferation. However, since inhibiting PDGF in the optic nerve eliminates only $70 \%$ of mitogenic activity, other signaling molecules must also play a role.

PDGFR $\alpha$ expression peaks on OPCs, then decreases as cells differentiate. However, adding FGF-2 reverses this effect by increasing PDGFR $\alpha$ expression, amplifying its response and stimulating long-term proliferation $[63,69,70]$. OPCs exposed to combined PDGF and FGF-2 continuously proliferate and self-renew, whereas if exposed to either PDGF or FGF-2 individually, progenitors exit the cell cycle [35], revealing these factors work synergistically to induce division and inhibit differentiation in a timely manner [71].

When acting alone, FGF-2 is a less potent mitogen than PDGF but still blocks OPC differentiation $[38,72,73]$. Developmentally, FGF-2 expression increases during proliferation and peaks during OL formation when it functions to regulate the number of mature OLs [74,75]. FGF-2 binds with high affinity to all four FGF receptors, but only fibroblast growth factors receptors 1-3 (FGFR1-3) affect OPC proliferation. In OPCs, FGFR-1 levels continually rise, therefore exposure to FGF-2 increases OPC migration and proliferation [75,76]. As early OPCs transition to late stage OPCs and FGRF-1 levels continue to rise, FGF-2 switches to inhibiting differentiation. Fibroblast growth factor receptor 1 small interfering RNA (siRNA) blocks this inhibition leading to a higher number of differentiated OLs, revealing that FGFR-1 halts OL differentiation [77]. Similar to FGFR-1, FGFR-3 expression also peaks in the late OL progenitor stage to further block OL differentiation. Later in development, FGF-2 severely disrupts myelin production by dysregulating myelin gene expression [78-80]. Overall, FGF-2 promotes the proliferation of OPCs by stimulating DNA synthesis and inhibiting OL lineage progression during all stages of development.

Insulin-like growth factor-1 (IGF-1) works in concert with PDGF and FGF-2 to promote OPC proliferation through binding the type 1 IGF receptor (IGFR1) [81,82]. PDGF increases IGFR1 expression, thereby potentiating IGF-1 effects and maximizing OPC proliferation [83]. Adding IGF-1 to OPCs isolated from perinatal rat cerebrum increases OPC proliferation six-fold [84,85]. Moreover, developmental IGF-1 overexpression accelerates the cell cycle and increases neuronal and OPC proliferation, leading to larger brain size and weight $[86,87]$.

The effects of IGF-1 depend on PI3K-Akt signaling, which promotes OPC survival and proliferation by inhibiting apoptosis and preventing the degradation of cyclin-D1 [88]. In addition, IGF-1 works synergistically with FGF-2 to activate the ERK1/2 pathway to stimulate cell growth and proliferation by upregulating nuclear cyclin-D expression [88-91]. Together, the PI3K/Akt and ERK1/2 pathways enhance G1/S progression, therefore IGF-1 shortens the cell cycle to allow increased cell proliferation [92]. In normal conditions, PDGF and FGF-2 trigger cells to enter G1 from the G0 phase. However, in conjunction with IGF-1, cells rapidly progress through G1 to the S phase due to upregulation of G1 cyclins, positive regulators of the cell cycle $[83,87,88,91,92]$. IGF-1-regulated PI3K-Akt signaling also functions as a survival signal by both protecting OPCs from tumor necrosis factor (TNF) $\alpha$-induced cell death and preventing apoptosis [86,93-95]. Thus, overall, IGF-1 acts as a progression factor that accelerates the cell cycle, and a survival factor that maintains OPC levels.

\subsubsection{Neurotrophic Factors}

Neurotrophins are soluble growth factors crucial for nervous system development. These factors, consisting of nerve growth factor (NGF), brain-derived neurotrophic factor (BDNF), neurotrophin-3 
(NT-3), and neurotrophin-4/5 (NT-4/5), are synthesized as precursor proteins, then cleaved into mature molecules. Mature neurotrophins signal through two distinct classes of receptors: the high-affinity receptor tyrosine kinase tropomyosin-related kinase (Trk), and the pan-neurotrophin receptor (p75NTR), a member of the TNF $\alpha$ receptor subfamily [96-98]. All neurotrophins bind with similar low affinity to p75NTR, but are selective in activating Trk receptors. Specifically, NGF binds TrkA, BDNF and NT- $4 / 5$ binds TrkB, and NT-3 binds TrkC $[99,100]$.

Neurotrophins exhibit mitogenic effects on OPCs, although BDNF effects appear to be region-dependent. For instance, BDNF is a potent mitogen for OPCs in the basal forebrain while having no effect on optic nerve OPCs [94,101]. Once TrkB is bound by BDNF, its cytoplasmic domain becomes phosphorylated, leading to mitogen-activated protein kinase (MAPK) activation and increased DNA synthesis [97,101,102].

Like BDNF, the proliferative effects of NT-3 are mediated through MAPK signaling, after binding to TrkC receptors [33,103]. In the optic nerve, NT-3 is a stronger mitogen than PDGF, although NT-3 requires IGF-1 to induce OPC proliferation, whereas PDGF can act alone [94,104]. Knockout models of NT-3 and TrkC show severe depletion in PDGFR $\alpha+$ OPCs in both the brain and spinal cord, although the distribution of OPCs in the CNS was similar to wild type, indicating NT-3 does not influence migration or distribution of OPCs [105]. In addition to acting as a mitogen during development, NT-3 is also a potent survival factor, promoting OPC survival in the absence of other trophic support [104].

\subsection{Differentiation}

The transition from progenitor cell to differentiated OLs involves multiple signals, including intracellular transcription factors and non-coding RNAs and extracellular molecules such as neurotransmitters, growth factors and extracellular matrix components (for an excellent recent review, see [5]). Changes in intracellular redox state may also be involved [57,106]. An additional molecular mechanism believed to underlie the switch in cell fate involves cyclin-dependent kinase-2 (Cdk2), which controls OPC cell cycle progression as it regulates the transition of cells from G1 to S phase $[107,108]$. To stop cell division, p27 binds to Cdk2 and promotes cell cycle arrest [109]. As OPCs proliferate, p27 slowly accumulates and regulates the timing of differentiation. If p27 is overexpressed, OPCs become unresponsive to mitogens resulting in significantly more mature OLs. Therefore, as time progresses, p27 levels reach a tipping point after which sufficient levels of Cdk2 are inhibited and cell proliferation is halted, in correlation with reduced PDGF and increased thyroid hormone (T3). Collectively, these experiments indicate OPC differentiation is regulated through multiple signaling mechanisms that ensure proper timing of OL maturation. Here, we will mainly focus on developmental factors that have also been examined in the injured CNS.

\subsubsection{Hormones}

Thyroid hormone is an important regulator of OPC differentiation. In the absence of T3 in culture, OPCs fail to differentiate and instead proliferate continuously [110-113]. Levels of T3 peak at birth and remain elevated for two weeks, coinciding with post-natal OL differentiation and myelination [114]. Once secreted, T3 binds to two receptors: T3 $\alpha$ on OPCs and T3 $\beta$ on mature OLs $[115,116]$. During myelination, T3 binds to T3 $\beta$ receptors and drives myelin basic protein (MBP) expression through direct interaction with the MBP promoter [117-119]. Mature OLs exposed to T3 also have increased branching, a morphology beneficial to myelination [118]. The diverse roles of T3 on OL development are likely due to distinct receptors, as T3 modulates OPC survival and OL differentiation through $\mathrm{T} 3 \alpha$ receptor and promotes myelination after cells upregulate $\mathrm{T} 3 \beta$ receptor.

In vitro about $80 \%$ of OPCs differentiate into OLs in the presence of IGF-1, whereas only $30 \%$ differentiate without it $[84,85]$. Conditional IGF-1 knockout mice show severely reduced brain size due to fewer OLs and axons, leading to an overall reduction in white matter [120,121], whereas excess IGF-1 inhibits OL apoptosis and promotes OL survival [122]. The higher number of mature OLs leads 
to increased MBP and proteolipid protein (PLP) expression, and a higher percentage of myelinated axons with thicker myelin [122-124]. Manipulating IGF-1 expression in vivo in either direction reveals the importance of IGF-1 in later stages, but due to its multiple roles throughout OL development, a model focused on OL maturation is more beneficial. Luzi et al. developed a transgenic mouse that overexpresses IGF-1 through the MBP promoter, thereby driving its overexpression only after myelination begins, around P10 [125]. The result was extensive myelination on axons due to more myelin produced per OL [125].

\subsubsection{Neurotrophic Factors}

Ciliary neurotrophic factor (CNTF) was originally identified for its role in neuronal support and survival [126], but since then, its importance in regulating OL development has become clear. CNTF is synthesized by astrocytes during the first postnatal week when OL generation peaks, and is continually expressed throughout early stages of oligodendrogenesis [127]. While CNTF does enhance the rate of OPC proliferation [128], it is more extensively involved in differentiation, maturation, and survival of OLs $[129,130]$. Spinal cord and cortical OPCs cultured in media supplemented with CNTF show increased differentiation, which is amplified when T3 is added [129,131]. Further in vitro studies uncovered a role for CNTF in myelination. When added to cultures, CNTF increased myelin production and the number of myelin internodes by upregulating MBP and myelin oligodendrocyte glycoprotein (MOG) expression $[130,132]$. Overexpressing CNTF in vivo is also correlated with increased MOG expression, while CNTF-deficient mice have higher rates of OL apoptosis and fewer myelinated axons $[133,134]$. Despite CNTF being a survival factor, the increased myelin gene expression is not due to increased OLs, but instead to more MBP and MOG expressed per OL [130].

Neurotrophin-3 plays a vital role in OL development. It is widely accepted that NT-3 promotes myelination and acts as a support factor in both the peripheral and central nervous system. It is highly expressed in the late prenatal period, peaks shortly after birth, then remains high 1-2 weeks postnatally before rapidly declining [135]. This expression pattern coincides with OPC differentiation and ultimately promotes axon myelination. Without NT-3, fewer OPCs differentiate, and those that do appear immature with short, stubby processes $[105,136]$. Overexpression of NT-3 in OPCs co-cultured with hippocampal neurons results in a 10-fold increase in MBP expression with a higher percent of axons becoming myelinated [137]. Thus, NT-3 is one of many influential signaling molecules in proper axon myelination.

Like NT-3, BDNF promotes myelin protein production in the peripheral nervous system (PNS) and CNS. In the PNS, BDNF activates p75NTR, while in the CNS it binds to TrkB, stimulating MAPK to upregulate MBP, PLP, and myelin-associated glycoprotein in OLs [102,138-140]. The need for BDNF developmentally is seen in BDNF null and heterozygous mice, which display hypomyelinated white matter due to reduced myelin gene expression [139,141-143]. This reduced myelin is not due to fewer myelinated axons, but instead thinner myelin per axon. Moreover, the number of differentiated OLs is comparable to controls, suggesting BDNF does not influence OL-axon contact, but may be necessary for establishing proper myelin thickness [144,145].

Neuregulin-1 (Nrg-1) is an extrinsic growth factor expressed by neurons in the brain and spinal cord that signals through ErbB receptor tyrosine kinases [146]. Initially, Nrg-1 was studied for its role in stimulating OPC proliferation; however, Nrg-1 is secreted throughout development and influences all stages of OL lineage cells, from proliferation through myelination [147-150]. Similar to PDGF, Nrg-1 stimulates OPC proliferation through the PI3K-Akt pathway [33,151,152]. Neuregulin works cooperatively with integrin signaling as ErbB2 associates with $\alpha_{\mathrm{v}} \beta_{3}$ on OPCs to stimulate proliferation via the PI3K-Akt pathway. This co-association is mediated by the Src family kinase (SFK) Lyn, a group of kinases that integrate external signals by regulating integrin and growth factor behaviors. As development progresses, OLs contact laminins which activate an integrin-regulated switch from proliferation to pro-differentiation and myelination. This switch reverses Nrg-1 inhibition of differentiation when Fyn, an SFK, binds integrin $\alpha_{6} \beta_{1}$ to change Nrg-1 signaling from PI3K-Akt to the 
MAPK pathway, thereby promoting myelination [151,152]. Blocking Erb signaling developmentally reduces differentiated OL number, and OLs that do differentiate fail to ensheath axons [153-155]. Together, these experiments suggest Nrg-1 signals through ErbB receptors and integrins to enhance OPC proliferation, differentiation, and OL myelination of axons.

CNS development is a sequential process that requires communication between secreted factors and their receptors (Figure 1), input from transcription factors (see reviews $[5,156,157]$ ), and cross talk between cell types. Oligodendrocyte progenitors migrate from the pMN domain of the neural tube, proliferate, differentiate into OLs, and then mature OLs myelinate axons. OPCs continue to proliferate and differentiate throughout adulthood, and OLs continuously generate new myelin to either replace myelin lost to aging or to accommodate new myelin in support of learning new tasks [55]. Myelination, a process tightly regulated during development, is disrupted after injury to the brain or spinal cord, altering the tissue milieu and complicating neural-glia interactions.

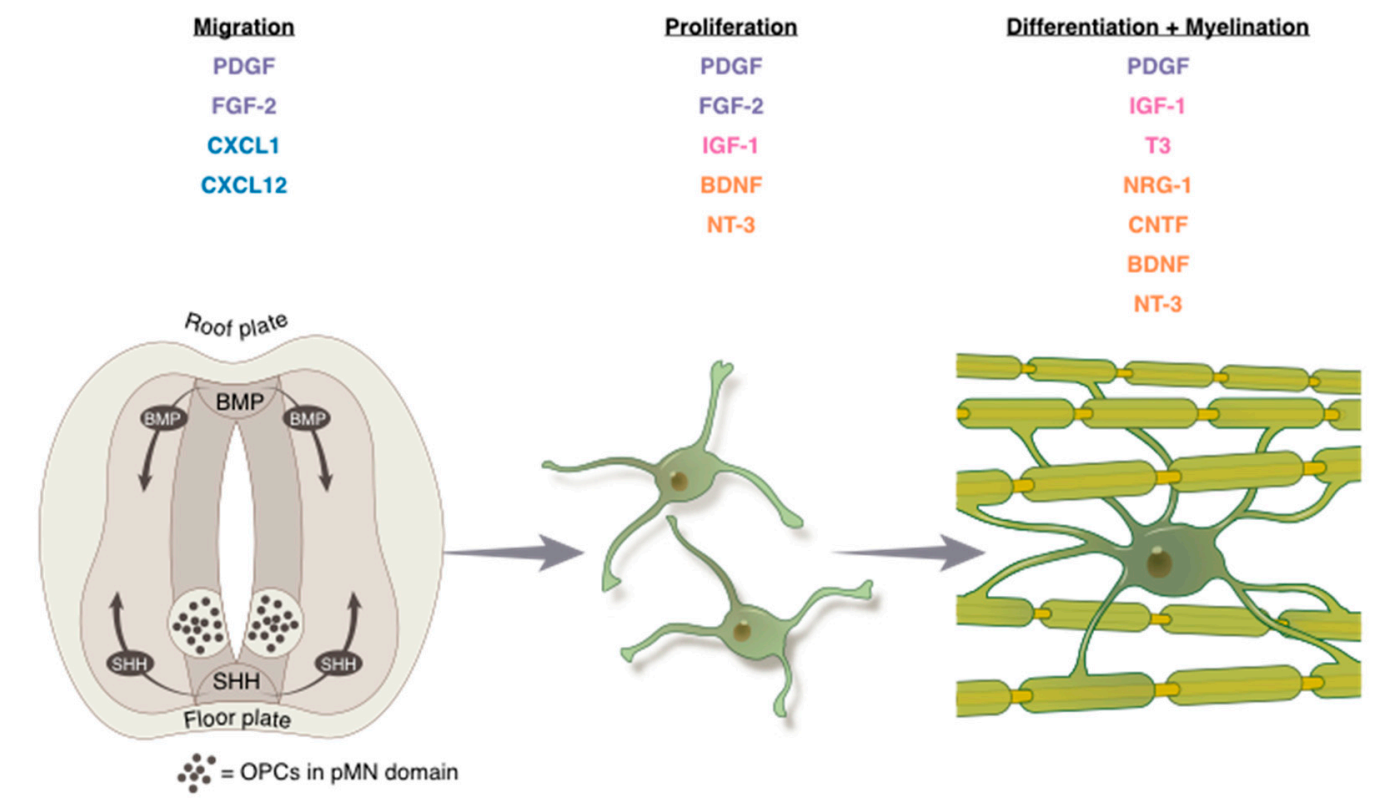

Figure 1. Environmental stimuli that influence the various stages of oligodendrocyte (OL) development. Oligodendrocyte progenitor cells (OPCs) originate in the neural tube, migrate dorsally and ventrally throughout the brain and spinal cord, proliferate, then differentiate into myelinating OLs. Environmental cues are grouped based category: growth factors (purple), chemokines (blue), hormones (pink), neurotrophic factors (orange). PDGF: platelet-derived growth factor; FGF-2: fibroblast growth factor-2; IGF-1: insulin-like growth factor-1; BDNF: brain-derived neurotrophic factor; NT-3: neurotrophin-3; T3: thyroid hormone; NRG-1: Neuregulin-1; CNTF: ciliary neurotrophic factor.

\section{Central Nervous System Trauma}

Brain and spinal cord trauma is characterized by a transient primary injury induced by a mechanical impact followed by protracted secondary injury processes. The hemorrhage, hypoxia, and extensive loss of neurons, glia, and axon tracts during the secondary injury phase is a large contributor to the cognitive, motor, and sensory dysfunction observed in human trauma patients and in pre-clinical models of central nervous system (CNS) trauma. In rodent models of spinal cord injury (SCI), there is a significant acute loss of OLs within $15 \mathrm{~min}$ at the injury epicenter that continues for at least 3 weeks post-injury (wpi) [158-161]. Traumatic brain injury (TBI) studies in rodents also show OLs within and proximal to the lesion are most susceptible to caspase-3-mediated apoptosis [162].

Myelinating OLs are terminally differentiated; thus, the primary source of post-injury myelin biogenesis is adult OPCs. Trauma to the CNS induces a robust oligodendrogenic response in which adult NG2+ OPCs proliferate in and around the injury epicenter and regenerate OLs that remyelinate 
spared axons [161,163-167]. Central canal ependymal cells can also proliferate and regenerate OLs, but this is specific to some models of SCI and has not been reproduced in other models of CNS insult [167-170]. Ultrastructural observations of axons in the injured cat spinal cord were among the first demonstrations of axon remyelination following CNS trauma [171,172]. Remyelinated axons are typically characterized by thinner myelin and shorter internodes, although myelin as thin as $3 \%$ of normal may still allow action potential conduction, revealing that thin myelin is likely preferable to no myelin $[173,174]$. Despite robust oligodendrogenesis persisting for at least 3 months post-injury (mpi) [164], spared axons experience a chronic increase in conduction block and their myelin displays a concurrent decrease in MBP messenger RNA (mRNA) expression [175], suggesting that endogenous remyelination of spared axons is suboptimal. Indeed, persistent myelin pathology has been detected for at least $10 \mathrm{wpi}$ in a pre-clinical rat SCI model $[164,176]$ and up to a decade after injury in some human SCI patients [177], making efforts to promote spontaneous myelin repair a promising therapeutic endeavor.

While necrosis and apoptosis are widely recognized as significant contributors to acute OL death after CNS injury $[158,162,178]$, the mechanisms behind chronic demyelination remain unknown. As in development, OL lineage cells are exquisitely sensitive to their environment. The factors, mitogens, and signaling cues that drive healthy development of OLs are largely dysregulated after CNS trauma, creating an environment in which functional myelin regeneration is potentially deterred. While the successful response of OL lineage cells to chemically induced focal demyelination has been well characterized, their response to the multiple biochemical cascades that define an injury microenvironment remains largely unknown. The following outlines primary components of the traumatically injured CNS milieu that are permissive or inhibitory for functional myelin repair (Figure 2). To develop effective therapeutics that provide meaningful recovery for CNS trauma patients, it is essential that we understand the impact of the injury microenvironment on spontaneous myelin repair and how the injury milieu changes over time.

\subsection{Growth Factors, Neurotrophic Factors, and Hormones Modulate Myelin Regeneration}

\subsubsection{Growth Factors}

The role of BMP proteins in adult myelin regeneration is not fully understood. Spinal cord injury induces BMP expression similar to other models of CNS injury $[164,165,179,180]$. While both BMP2 and BMP4 inhibit the early stages of OPC differentiation during development, BMP4 is the primary BMP member to inhibit OL lineage cell differentiation after CNS trauma [181-183]. Indeed, inhibiting BMP4 signaling promotes OL regeneration and axon remyelination and decreases glial scarring in models of CNS trauma and chemically induced demyelination [179,182,184].

During development, exposure to PDGF promotes OPC proliferation by activating Wnt- $\beta$-catenin signaling [53]. The pattern of expression of Wnt signaling is modulated by SCI $[53,185,186]$. Moreover, genetic deletion of $\beta$-catenin from PDGFR $\alpha$-expressing cells suppressed OPC proliferation and accumulation around the SCI epicenter [187]. Thus, increased exposure to PDGFA could potentially stimulate Wnt/ $\beta$-catenin activation and promote OPC proliferation following SCI.

OPC differentiation and remyelination of spared axons are also modulated post-injury by PDGF-A, which primarily upregulates Olig2 [61,188]. Evidence suggests that PDGF-A positively modulates OL lineage cells via synergistic effects with components of the extracellular matrix and other pro-proliferation growth factors, such as FGF-2 and IGF-1, which are upregulated for weeks after SCI [68,164,189-191]. After experimental rat SCI, intraspinal transplantation of Schwann cells promotes host OPC proliferation and recruitment to the lesion via secretion of FGF-2 and PDGF-A, a treatment that promoted remyelination of spared axons and enhanced recovery of function [188]. Further studies evaluating the synergistic effects of these protective, pro-OL lineage growth factors could provide novel therapeutic avenues that robustly promote OPC proliferation and differentiation. 


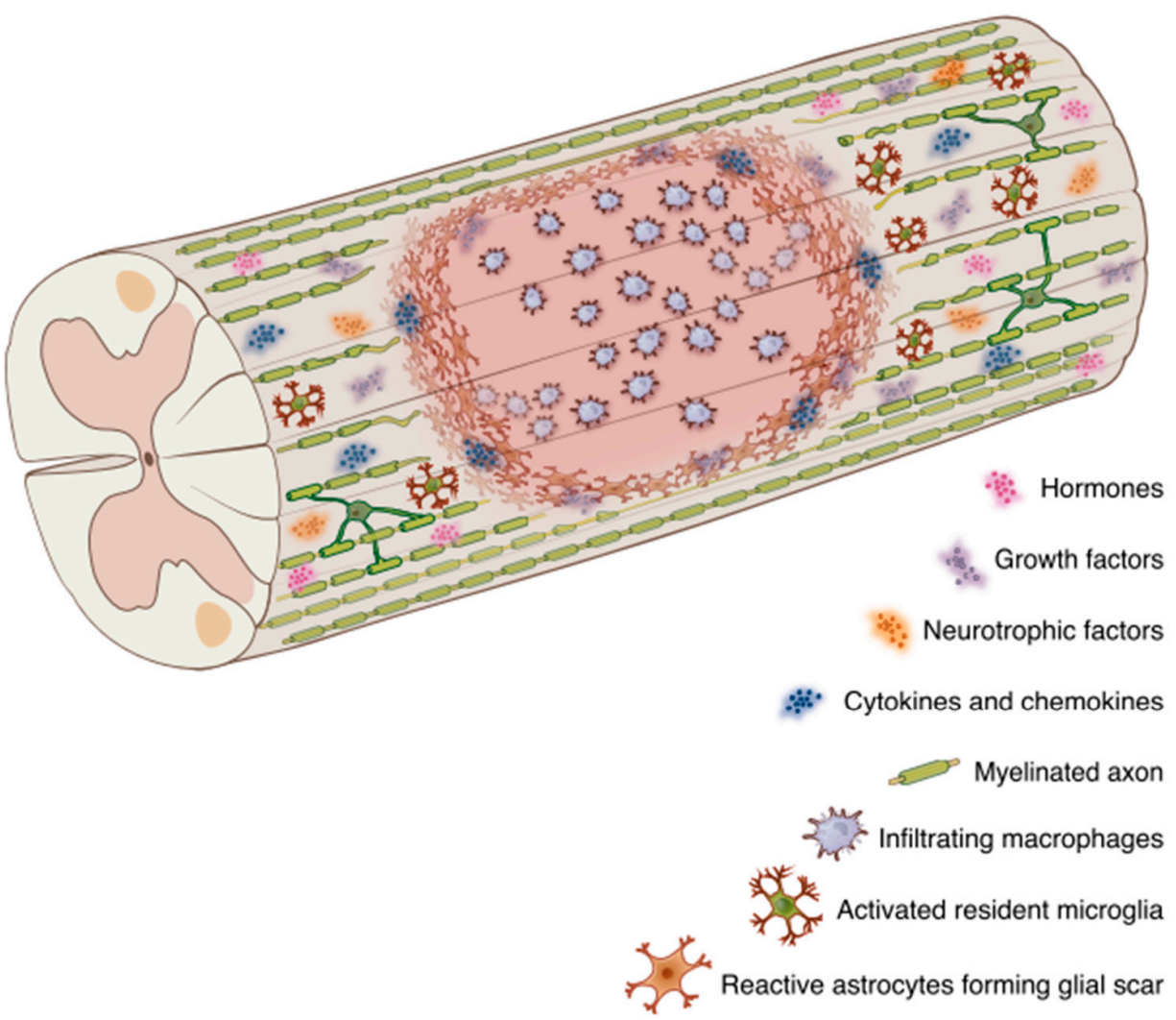

Figure 2. Primary factors that define a central nervous system (CNS) injury milieu. The injury microenvironment impacts the ability for OL lineage cells to effectively remyelinate all spared axons. Hormones (pink), growth factors (purple) and neurotrophic factors (orange) that promote myelination during development are dysregulated after spinal cord injury. Reactive astrocytes and immune cells (macrophages and microglia) secrete pro-reparative and pro-inflammatory cytokines and chemokines that differentially affect OL lineage cells.

\subsubsection{Neurotrophic Factors}

Ciliary neurotrophic factor is a pro-reparative protein that protects OPCs from TNF $\alpha$-induced apoptosis and promotes proliferation during development and after CNS injury [94,192]. Following TBI and SCI in adult rat models, both CNTF and FGF-2 are upregulated acutely and remain elevated chronically, particularly within the glial scar and in regions of increased OPC proliferation [164,191,193,194] suggesting that CNTF is a somewhat "permanent" component of a microenvironment permissive to OL lineage cells. Indeed, transplanting OPCs overexpressing CNTF into the injured adult rat cord not only promotes OPC survival and axon remyelination, but also significantly restores signal conduction of demyelinated axons and improves recovery of hindlimb motor function [195]. Thus, CNTF's pro-proliferative and pro-survival role in development is maintained after CNS injury, making it a promising therapeutic factor in promoting myelin regeneration.

The developmental role of NT-3 in promoting OPC survival and maturation is potentiated after injury. Neurotrophin-3 can promote the in vitro survival of OLs at a higher rate than CNTF, and stimulates OPC proliferation and axon remyelination in vivo [94,196]. The effect of NT-3 on OL lineage cells becomes increasingly neuroprotective in synergy with other intrinsic and extrinsic factors both during development and after trauma. For example, the effect of NT-3 on developmental OL survival is potentiated in the presence of PDGF [94]. Similarly, co-expression of NT-3 and BDNF in the injured adult rat spinal cord not only promotes regeneration of propriospinal axons but also stimulates OL lineage cell proliferation and axon remyelination [104,196,197]. Moreover, co-expression of NT-3 and Shh increases Olig2+ cell number and enhances remyelination after injury to 
the adult mouse spinal cord [198]. Transplanting fibrin scaffolds loaded with purified neural progenitor cells, NT-3, and PDGF-AA into the acutely injured mouse spinal cord establishes a pro-reparative microenvironment in which tissue sparing is promoted and OL differentiation and axon remyelination is increased [199].

After rat spinal contusion, neurons and glia upregulate BDNF acutely, suggesting it is in position to play a neuroprotective role during the secondary injury processes [200-202]. BDNF treatment increases MBP expression in spared white matter of the spinal cord, promotes long-term OL survival and axon remyelination, and increases functional recovery $[196,203,204]$. Brain-derived neurotrophic factor and IGF-1 synergistically attenuate expression of nitric oxide synthase, a mediator of OL death in several demyelinating conditions, including SCI [205-207]. Moreover, intrathecal administration of BDNF promotes OL survival by preventing downregulation of $\mathrm{Cu} / \mathrm{Zn}$ superoxide dismutase (CuZnSOD), an antioxidant that limits cell death by attenuating the formation of reactive oxygen species (ROS). Brain-derived neurotrophic factor also promotes myelin regeneration after CNS injury by positively modulating pro-myelinating transcription factors, such as Olig2, as well as promoting expression of PLP, a major myelin protein [208-210]. While the primary developmental role of BDNF is to modulate myelin thickness, BDNF becomes a potent extrinsic regulator of OPC differentiation and OL survival after CNS injury and may have significant potential in translational clinical applications.

The developmental role of Nrg-1 in stimulating OPC proliferation, survival, and differentiation is conserved after adult CNS injury. Intrathecal administration of Nrg-1 enhances OPC differentiation, promotes survival of existing OPCs, and stimulates remyelination by newly generated OLs and infiltrating Schwann cells $[148,211,212]$. Additionally, selectively ablating Nrg-1 prevents CNS OL lineage cells from differentiating into peripheral-like Schwann cells that remyelinate spared axons [212]. As Nrg-1 levels significantly drop acutely after injury and remain profoundly low chronically [148], perhaps Nrg-1 deregulation, which impacts signaling cascades integral for proliferation and cell survival, contributes to impaired OPC proliferation and maturation. Dysregulated levels of Nrg-1 in the spinal cord have recently been suggested to underlie myelin thinning on remyelinated axons [211]. Neuregulin-1 is also suggested to modulate the reparative and pro-inflammatory response of glial cells to CNS trauma. The immediate administration of Nrg-1 after rat-compressive SCI deceases pro-inflammatory components (e.g., interleukin (lL)- $1 \beta, \mathrm{TNF} \alpha$, nitric oxide) and harmful matrix metalloproteinases. It also increases factors characteristic of a pro-reparative permissive environment, such as IL-10 and arginase-1 $[148,213]$. The effects of Nrg-1 on OL lineage cells, as well as its ability to modulate the inflammatory response to trauma, make Nrg-1 therapy a promising direction in CNS injury research.

\subsubsection{Hormones}

Thyroid hormone, a potent regulator of the timing of developmental OL differentiation, is also modulated by CNS trauma. Thyroid hormone levels are significantly lower in SCI patients, both acutely and chronically, compared to non-injured individuals [214,215]. In vitro studies demonstrate that compared to BDNF and NT-3, T3 is more potent in stimulating OL differentiation [216]. Moreover, local delivery of $\mathrm{T} 3$ directly to the spinal cord significantly accelerates oligodendrogenesis and axon myelination following cervical contusion injury [216]. While the beneficial effects of T3 have been extensively studied in multiple sclerosis (MS) and other demyelinating conditions, further work is needed in models of CNS trauma to fully elucidate its potential in myelin repair.

A key player in both CNS and PNS reparative processes, IGF-1 is secreted by astrocytes, microglia, and macrophages after CNS injury [217-219]. It stimulates OPC proliferation and differentiation, increases myelin related gene expression, and decreases astrogliosis after CNS injury [220-223]. Moreover, IGF-1 robustly promotes OPC survival and OL maturation via synergistic effects with other growth factors, including BDNF, PDGF, and NT-3 [205,224]. Systemic administration of IGF-1 reverses TBI-induced reductions in NT-3 and BDNF, inhibits OL apoptosis, and improves injury outcome [224]. Neurological outcome after traumatic brain and spinal cord injury in humans has been linked to 
IGF-1 levels in peripheral blood serum. Patients with elevated serum IGF-1 levels demonstrate greater neurological improvement chronically compared to those with lower serum IGF-1 [225,226]. Levels of IGF-1 may be elevated in response to prolonged injury-associated inflammation, and exogenous IGF-1 treatment could potentially supplement the neuroprotective role of IGF-1 and serve as a potent therapeutic target.

Progesterone (P4) is an endogenous hormone and steroid from the progestogens family and has emerged as a neuroprotective strategy to promote endogenous repair. Daily progesterone treatments between three to five days following SCI in rats reduces the lesion size, stimulates OPC proliferation, and increases mRNA expression of Olig2 and Nkx2.2, a major OPC specification protein [227-229]. Continued administration of $\mathrm{P} 4$ for 21 days in a complete SCI rat model increases newly differentiated OLs and stimulates Olig1 expression, a transcription factor that promotes myelin regeneration [228,230]. Systemic progesterone treatment following TBI in rats also significantly attenuates secondary pathology and improves behavioral function, but its ability to restore white matter integrity has yet to be evaluated in these models [231,232].

\subsection{Components of the Injury-Induced Glial Scar Affect OL Lineage Cells}

Central nervous system trauma promotes the formation of a glial scar whose primary astrocytic component secretes chondroitin sulfate proteoglycans (CSPGs) [233]. These CSPGs negatively regulate OL lineage cells both in vitro and in vivo [234,235]. Macrophage-secreted transforming growth factor (TGF) $\beta$ can also induce CSPG upregulation via PI3K-Akt-mTOR signaling [236-238]. Evidence suggests there is a relationship between the concentrations of CSPG and the degree of remyelination of spared axons $[233,239]$. Not only do CSPGs deter axon regeneration, but they also signal through PTPo receptors to inhibit OL process outgrowth and axon myelination [235]. Several studies have targeted CSPGs and while these have proven effective in reducing tissue damage and promoting axon growth, only CSPG degradation using chondroitinase $A B C$ (ChABC) treatment, or ChABC combined with a cocktail of growth factors (FGF, PDGF) has successfully promoted OL differentiation after SCI $[169,235,240,241]$.

Macrophage and glial-scar-derived Endothelin-1, LRR and Ig domain-containing, Nogo Receptorinteracting protein (LINGO-1), TNF $\alpha$, and IL-1 $\beta$ also suppress OPC differentiation and OL maturation [242-244]. It is important to note, however, that both TNF $\alpha$ and IL-1 $\beta$ also positively modulate OL lineage cells. Mice lacking TNF $\alpha$ and its associated receptor, TNFR2, have a significant delay in remyelination after toxin-induced demyelination [245]. Interleukin-1 $\beta$ can also induce OPC differentiation and promote OL survival; however, in the presence of PDGF and FGF in vitro, it arrests OPC proliferation [246]. These lines of evidence suggest that further research is needed to elucidate the interactions of astrocyte- and macrophage-derived cytokines with OL lineage cells and the ways in which their response to demyelination and trauma may change over time.

Astrocytes can positively modulate remyelination by their ability to produce CNTF and take up significant amounts of iron, maintaining the homeostasis that is necessary for the proliferation, maturation, and survival of OL lineage cells [164,247,248]. Notably, prior work from our lab demonstrated the SCI-induced glial scar is an area of robust OPC proliferation and accumulation as well as OL differentiation and myelination $[164,249]$. This area contains high levels of pro-oligogenic factors CNTF, FGF-2, and peroxisome proliferator-activated receptor delta (PPAR- $\delta$ ), an intracellular nuclear receptor that promotes OL differentiation $[164,191,250]$. Notably, when proliferating NG2+ OPCs (and pericytes) were ablated after SCI, the astrocytic glial scar was significantly less dense and more axons spontaneously grew into the lesions, revealing OPCs not only respond to their environment but also affect the response of other post-injury parenchymal elements [251]. Astrocyte-oligodendrocyte crosstalk drives developmental myelin formation, trauma-induced myelin damage, and spontaneous axon remyelination. Thus, clarifying the complex mechanisms behind astrocyte-OL lineage crosstalk could potentially lead to novel therapeutics in which the beneficial effects of astrocytes and OPCs are harnessed and the detrimental effects are attenuated. 


\subsection{The Neuroimmune Axis}

In the homeostatic CNS, the balance of genes expressed by adult OPCs are similar to OLs [252]. However, in response to toxin-induced demyelination, OPCs revert to a neonatal transcriptome and increase expression of IL-1 $\beta$ and CCL2, immune cues that promote progenitor cell migration [252,253]. On the other hand, several chemokines and cytokines can inhibit OPC differentiation and axon remyelination $[213,246,254]$ suggesting that a neuroimmune axis exists that may dynamically modulate OL lineage cells and myelin repair after CNS trauma [255].

\subsubsection{Cytokines and Microglia/Macrophage Signaling}

Activated macrophages, a population composed of resident microglia and infiltrating monocytes, play divergent pro-inflammatory and pro-reparative roles in response to CNS trauma. Pro-inflammatory M1 polarized macrophages secrete toxic cytokines, chemokines, reactive oxygen species, and promote excitotoxicity—all of which engender a microenvironment inhibitory for OL regeneration [253].

Pro-reparative M2 macrophages not only facilitate the clearance of myelin debris that can inhibit OL differentiation but also secrete factors that stimulate OL differentiation and remyelination, such as IL-10, leukemia inhibitory factor (LIF), CNTF, and, TGF $\beta$ [256-258]. Experimental strategies in SCI models where LIF is administered arrests OL death, enhances OL differentiation, and promotes OL survival by activating the Janus kinase- signal transducers and activators of transcription (JAK-STAT) and Akt pathways [259-261]. However, evidence from a mouse model of MS suggests that while LIF administration promotes axon remyelination, it fails to increase the thickness of regenerated myelin [262]. Transforming growth factor- $\beta$ is suggested to potently regulate the initiation and resolution of inflammation [263]. Indeed, following spinal contusion, TGF $\beta$ mRNA levels are significantly elevated, particularly in regions of dense microglia and macrophages [264]. Attenuation of TGF $\beta$ following SCI decreases fibrotic scar formation, and promotes axon regeneration through lesion $[265,266]$; remyelination, however, was not evaluated in that study.

The mechanism of microglia and macrophage activation also has consequences for OL lineage cells (for a recent review, see [267]). For instance, in vivo activation of the Toll-like receptor 2 (TLR2) on microglia and macrophages results in death of all OPCs and OLs (and astrocytes) in the region [268]. However, intraspinal activation of the receptor TLR4 causes initial demyelination and loss of OPCs and OLs, followed by subsequent and robust OPC proliferation and migration into the area of activated macrophages, after which a significant portion of OPCs differentiate into new OLs [268,269]. Notably, this oligodendrogenic response depended on sufficient iron levels and we showed that macrophages can transfer iron-containing ferritin to OPCs in vivo $[270,271]$. This may be an intriguing mechanism of OL genesis after SCI since TLR4 is activated on microglia and macrophages after SCI and this signaling pathway induces iron uptake by macrophages $[272,273]$. The SCI site is rich in iron due to intraspinal hemorrhage and cell death, and iron-laden macrophages accumulate acutely and are sustained chronically in the injured spinal cord [274-276]. Notably, in the absence of TLR4 signaling after SCI, OPC accumulation and OL production are significantly reduced [273]. Microglia play a central role in CNS development and myelin biogenesis; thus, the ways in which activated microglia and macrophages influence OL lineage cells after CNS trauma needs further study as it could provide important insight into how the neuroimmune axis can be harnessed to promote myelin repair.

\subsubsection{Cytokine Signaling Regulators}

Suppressors of cytokine signaling (SOCS) proteins are key components of the innate and adaptive immune system (extensively reviewed in [277]). Cytokines and interleukins induce SOCS expression via JAK/STAT signaling. SOCS, in turn, inhibits the JAK/STAT pathway and negatively regulates cytokine signaling [278-280]. Of the SOCS protein family, SOCS1 and SOCS3 have been best characterized in their response to CNS trauma and their differential influence on endogenous 
myelin repair. SOCS1 proteins positively modulate pro-reparative M2 macrophage polarization and attenuate pro-inflammatory M1 macrophages [281]. Enhanced expression of SOCS1 in a mouse model of contusive SCI is linked to improved sensory and locomotor function, decreased demyelination, and reduced pro-inflammatory cytokine expression [282]. On the other hand, SOCS3 expression is upregulated by M1 polarized macrophages within pro-inflammatory environments [283]. Inhibition of SOCS3 activity in rodents attenuates demyelination, enhances NG2+ cell proliferation, and promotes OL survival after SCI $[279,284,285]$. Understanding the expression and function of SOCS proteins in CNS trauma may hold promise for immunomodulatory therapeutics that suppress a hostile trauma microenvironment and promote myelin repair.

\subsubsection{Chemokines}

Several chemokines and cytokines in the C-X-C family have been implicated in the response of OL lineage cells to CNS trauma.

Following mid-thoracic SCI in adult mice, there is a significant and persistent upregulation of CX3CR1 expression, a microglia-specific receptor for fractalkine [286]. Genetic deletion of CX3CR1 modulates macrophages towards a pro-reparative phenotype, enhances NG2 responses to injury, and increases myelin and axon sparing at the lesion epicenter [286,287].

CXCL12 and its receptor, CXCR4, are expressed by PDGFR $\alpha+$ OPCs and positively modulate OPC proliferation, survival, migration, and differentiation after CNS trauma [50,51,288,289]. Reactive astrocytes in regions of demyelination upregulate CXCL12, which has been proposed to serve as a potent chemoattractant to guide migrating oligodendrocyte precursor cells to the injury site and promote their differentiation [290].

Both CXCL1 and its receptor, CXCR2, are upregulated after CNS injury [289]. During development, CXCL1 primarily promotes OPC proliferation; however, after injury, CXCL1 signaling promotes OPC survival by restricting interferon (IFN)- $\gamma$ - and CXCL10-induced apoptosis [44,291]. Evidence from the experimental allergic encephalomyelitis (EAE) model demonstrates that CXCL1 overexpression can rescue OPCs from apoptosis and significantly reduce the severity of myelin pathology [292], though this has yet to be shown in SCI. The CXCR2 receptor is expressed on human OLs [293], and CXCL1 ligand has been detected on human-activated microglia and reactive astrocytes [294,295] making this chemokine and its modulation of OL lineage cells a potentially translatable focus of study that should be explored further within the pathology of brain and spinal cord injury.

\section{Summary and Conclusions}

Myelination is an evolutionarily advantageous specialization that enables rapid communication between neurons in the CNS. Oligodendrocyte lineage cells are incredibly sensitive to their environment. A healthy microenvironment is integral for myelin biogenesis during development as well myelin maintenance in adults and repair following CNS trauma. Mechanisms regulating OL progression during development are well studied; however, the individual and synergistic roles of these regulatory factors after CNS trauma are not fully understood. Overwhelming evidence demonstrates the ways in which downregulating beneficial factors combined with the poor resolution of pro-inflammatory factors hinders endogenous axon remyelination. Thus, manipulating various components of the injury milieu is a promising strategy to promote spontaneous myelin repair. For instance, understanding the synergistic effects of pro-myelination growth factors and hormones could inform the development of treatments that harness their synergistic neuroprotective effects. Importantly, future work aimed at promoting myelin repair should also focus on elucidating the effects of glial cross talk on endogenous remyelination. While the physiology and pathophysiology of individual glial cells in a trauma microenvironment is incompletely understood [243], clarifying how OL lineage cells are influenced by astrocytes and microglia/macrophages could not only provide insight into the importance of glial cross talk during development but also provide novel avenues through which those signaling pathways can be harnessed to promote myelin repair. 
With the rising field of tissue engineering and the significant strides made in stem cell biology, several of the beneficial and toxic factors that comprise post-injury milieu can be manipulated to promote CNS injury repair [296]. Additionally, the prevalent and validated use of transgenic mice with inducible gene expression has allowed for the evaluation of pro-myelination developmental factors within the post-injury microenvironment. For instance, myelin regulatory factor (MYRF), a factor critical for myelination during development, is expressed by newly generated OLs in response to induced focal demyelination and is required for new OL genesis [297]. The recent use of mice in which OPC-specific MYRF can be deleted or inducibly expressed is promising for research aimed towards promoting myelin repair after CNS trauma. To develop novel therapeutics geared to promote myelin regeneration after CNS injury, it is vital that the factors driving healthy myelin development are manipulated after injury to support OL lineage progression. Harnessing these pathways to improve myelin repair may promote meaningful functional recovery for patients.

Author Contributions: N.P. and R.Y., contributed the original draft preparation; D.M.M., N.P., and R.Y., reviewed and edited the paper.

Acknowledgments: We would like to thank Anthony Baker of the Ohio State University Neurological Institute for the manuscript illustrations.

Conflicts of Interest: The authors declare no conflict of interest.

\section{References}

1. Boullerne, A.I. The history of myelin. Exp. Neurol. 2016, 283, 431-445. [CrossRef] [PubMed]

2. Rasband, M.N.; Peles, E. The Nodes of Ranvier: Molecular Assembly and Maintenance. Cold Spring Harb. Perspect. Biol. 2015, 8, a020495. [CrossRef] [PubMed]

3. Pan, S.; Chan, J.R. Regulation and dysregulation of axon infrastructure by myelinating glia. J. Cell Biol. 2017, 216, 3903-3916. [CrossRef] [PubMed]

4. Zalc, B. The acquisition of myelin: An evolutionary perspective. Brain Res. 2016, 1641, 4-10. [CrossRef] [PubMed]

5. Santos, A.K.; Vieira, M.S.; Vasconcellos, R.; Goulart, V.A.M.; Kihara, A.H.; Resende, R.R. Decoding cell signalling and regulation of oligodendrocyte differentiation. Semin. Cell Dev. Biol. 2018. [CrossRef] [PubMed]

6. Nishiyama, A.; Boshans, L.; Goncalves, C.M.; Wegrzyn, J.; Patel, K.D. Lineage, fate, and fate potential of NG2-glia. Brain Res. 2016, 1638, 116-128. [CrossRef] [PubMed]

7. Nishiyama, A.; Komitova, M.; Suzuki, R.; Zhu, X. Polydendrocytes (NG2 cells): multifunctional cells with lineage plasticity. Nat. Rev. Neurosci. 2009, 10, 9-22. [CrossRef] [PubMed]

8. Watanabe, M.; Toyama, Y.; Nishiyama, A. Differentiation of proliferated NG2-positive glial progenitor cells in a remyelinating lesion. J. Neurosci. Res. 2002, 69, 826-836. [CrossRef] [PubMed]

9. Gans, C.; Northcutt, R.G. Neural crest and the origin of vertebrates: a new head. Science 1983, 220, $268-273$. [CrossRef] [PubMed]

10. Noll, E.; Miller, R.H. Oligodendrocyte precursors originate at the ventral ventricular zone dorsal to the ventral midline region in the embryonic rat spinal cord. Development 1993, 118, 563-573. [PubMed]

11. Rowitch, D.H. Glial specification in the vertebrate neural tube. Nat. Rev. Neurosci. 2004, 5, 409-419. [CrossRef] [PubMed]

12. Richardson, W.D.; Kessaris, N.; Pringle, N. Oligodendrocyte wars. Nat. Rev. Neurosci. 2006, 7, 11-18. [CrossRef] [PubMed]

13. Tripathi, R.B.; Clarke, L.E.; Burzomato, V.; Kessaris, N.; Anderson, P.N.; Attwell, D.; Richardson, W.D. Dorsally and ventrally derived oligodendrocytes have similar electrical properties but myelinate preferred tracts. J. Neurosci. 2011, 31, 6809-6819. [CrossRef] [PubMed]

14. Levison, S.W.; Goldman, J.E. Both oligodendrocytes and astrocytes develop from progenitors in the subventricular zone of postnatal rat forebrain. Neuron 1993, 10, 201-212. [CrossRef]

15. Lachapelle, F.; Gumpel, M.; Baulac, M.; Jacque, C.; Duc, P.; Baumann, N. Transplantation of CNS Fragments into the Brain of Shiverer Mutant Mice: Extensive Myelination by Implanted Oligodendrocytes. Dev. Neurosci. 1983, 6, 325-334. [CrossRef] [PubMed] 
16. Cai, J.; Qi, Y.; Hu, X.; Tan, M.; Liu, Z.; Zhang, J.; Li, Q.; Sander, M.; Qiu, M. Generation of Oligodendrocyte Precursor Cells from Mouse Dorsal Spinal Cord Independent of Nkx6 Regulation and Shh Signaling. Neuron 2005, 45, 41-53. [CrossRef] [PubMed]

17. Jessell, T.M. Neuronal specification in the spinal cord: inductive signals and transcriptional codes. Nat. Rev. Genet. 2000, 1, 20-29. [CrossRef] [PubMed]

18. Mekki-Dauriac, S.; Agius, E.; Kan, P.; Cochard, P. Bone morphogenetic proteins negatively control oligodendrocyte precursor specification in the chick spinal cord. Development 2002, 129, 5117-5130. [PubMed]

19. Bond, A.M.; Bhalala, O.G.; Kessler, J.A. The dynamic role of bone morphogenetic proteins in neural stem cell fate and maturation. Dev. Neurobiol. 2012, 72, 1068-1084. [CrossRef] [PubMed]

20. Kessaris, N.; Fogarty, M.; Iannarelli, P.; Grist, M.; Wegner, M.; Richardson, W.D. Competing waves of oligodendrocytes in the forebrain and postnatal elimination of an embryonic lineage. Nat. Neurosci. 2006, 9 , 173-179. [CrossRef] [PubMed]

21. Hughes, E.G.; Kang, S.H.; Fukaya, M.; Bergles, D.E. Oligodendrocyte progenitors balance growth with self-repulsion to achieve homeostasis in the adult brain. Nat. Neurosci. 2013, 16, 668-676. [CrossRef] [PubMed]

22. Kirby, B.B.; Takada, N.; Latimer, A.J.; Shin, J.; Carney, T.J.; Kelsh, R.N.; Appel, B. In vivo time-lapse imaging shows dynamic oligodendrocyte progenitor behavior during zebrafish development. Nat. Neurosci. 2006, 9 , 1506-1511. [CrossRef] [PubMed]

23. Chong, S.Y.C.; Rosenberg, S.S.; Fancy, S.P.J.; Zhao, C.; Shen, Y.-A.A.; Hahn, A.T.; McGee, A.W.; Xu, X.; Zheng, B.; Zhang, L.I.; et al. Neurite outgrowth inhibitor Nogo-A establishes spatial segregation and extent of oligodendrocyte myelination. Proc. Natl. Acad. Sci. USA 2012, 109, 1299-1304. [CrossRef] [PubMed]

24. Richardson, W.D.; Pringle, N.; Mosley, M.J.; Westermark, B.; Dubois-Dalcqt, M. A Role for Platelet-Derived Growth Factor in Normal Gliogenesis in the Central Nervous System. Cell 1988, 53, 309-319. [CrossRef]

25. Pringle, N.P.; Mudhar, H.S.; Collarini, E.J.; Richardson, W.D. PDGF receptors in the rat CNS: during late neurogenesis, PDGF alpha- receptor expression appears to be restricted to glial cells of the oligodendrocyte lineage. Development 1992, 115, 535-551. [PubMed]

26. Frost, E.E.; Zhou, Z.; Krasnesky, K.; Armstrong, R.C. Initiation of oligodendrocyte progenitor cell migration by a PDGF-A activated extracellular regulated kinase (ERK) signaling pathway. Neurochem. Res. 2009, 34, 169-181. [CrossRef] [PubMed]

27. Kennedy, T.E.; Serafini, T.; de la Torre, J.; Tessier-Lavigne, M. Netrins are diffusible chemotropic factors for commissural axons in the embryonic spinal cord. Cell 1994, 78, 425-435. [CrossRef]

28. Jarjour, A.A.; Manitt, C.; Moore, S.W.; Thompson, K.M.; Yuh, S.-J.; Kennedy, T.E. Netrin-1 is a chemorepellent for oligodendrocyte precursor cells in the embryonic spinal cord. J. Neurosci. 2003, 23, 3735-3744. [CrossRef] [PubMed]

29. Hart, I.K.; Richardson, W.D.; Heldin, C.-H.; Westermark, B.; Raff, M.C. PDGF receptors on cells of the oligodendrocyte-type-2 astrocyte (O-2A) cell lineage. Development 1989, 105, 595-603. [PubMed]

30. Tsai, H.-H.; Tessier-Lavigne, M.; Miller, R.H. Netrin 1 mediates spinal cord oligodendrocyte precursor dispersal. Development 2003, 130, 2095-2105. [CrossRef] [PubMed]

31. Tsai, H.-H.; Macklin, W.B.; Miller, R.H. Netrin-1 is required for the normal development of spinal cord oligodendrocytes. J. Neurosci. 2006, 26, 1913-1922. [CrossRef] [PubMed]

32. Leferink, P.S.; Breeuwsma, N.; Bugiani, M.; van der Knaap, M.S.; Heine, V.M. Affected astrocytes in the spinal cord of the leukodystrophy vanishing white matter. Glia 2018, 66, 862-873. [CrossRef] [PubMed]

33. Baron, W.; Shattil, S.J.; ffrench-Constant, C. The oligodendrocyte precursor mitogen PDGF stimulates proliferation by activation of alpha(v)beta3 integrins. EMBO J. 2002, 21, 1957-1966. [CrossRef] [PubMed]

34. Ferrara, N.; Ousley, F.; Gospodarowicz, D. Bovine brain astrocytes express basic fibroblast growth factor, a neurotropic and angiogenic mitogen. Brain Res. 1988, 462, 223-232. [CrossRef]

35. Wolswijk, G.; Noble, M. Cooperation Between PDGF and FGF Converts Slowly Dividing O-2A adutt Progenitor Cells to Rapidly Dividing Cells with Characteristics of O_2A perinatal Progenitor Cells. J. Cell Biol. 1992, 118, 889-900. [CrossRef] [PubMed]

36. Milner, R.; Anderson, H.J.; Rippon, R.F.; McKay, J.S.; Franklin, R.J.M.; Marchionni, M.A.; Reynolds, R.; Ffrench-Constant, C. Contrasting effects of mitogenic growth factors on oligodendrocyte precursor cell migration. Glia 1997, 19, 85-90. [CrossRef] 
37. Vora, P.; Pillai, P.P.; Zhu, W.; Mustapha, J.; Namaka, M.P.; Frost, E.E. Differential effects of growth factors on oligodendrocyte progenitor migration. Eur. J. Cell Biol. 2011, 90, 649-656. [CrossRef] [PubMed]

38. Chen, Y.-J.; Zhang, J.-X.; Shen, L.; Qi, Q.; Cheng, X.-X.; Zhong, Z.-R.; Jiang, Z.-Q.; Wang, R.; Lü, H.-Z.; $\mathrm{Hu}$, J.-G. Schwann cells induce Proliferation and Migration of Oligodendrocyte Precursor Cells Through Secretion of PDGF-AA and FGF-2. J. Mol. Neurosci. 2015, 56, 999-1008. [CrossRef] [PubMed]

39. Murcia-Belmonte, V.; Medina-Rodríguez, E.M.; Bribián, A.; de Castro, F.; Esteban, P.F. ERK1/2 signaling is essential for the chemoattraction exerted by human FGF2 and human anosmin-1 on newborn rat and mouse OPCs via FGFR1. Glia 2014, 62, 374-386. [CrossRef] [PubMed]

40. Osterhout, D.J.; Ebner, S.; Xu, J.; Ornitz, D.M.; Zazanis, G.A.; McKinnon, R.D. Transplanted oligodendrocyte progenitor cells expressing a dominant-negative FGF receptor transgene fail to migrate in vivo. J. Neurosci. 1997, 17, 9122-9132. [CrossRef] [PubMed]

41. Robinson, S.; Tani, M.; Strieter, R.M.; Ransohoff, R.M.; Miller, R.H. The chemokine growth-regulated oncogene-alpha promotes spinal cord oligodendrocyte precursor proliferation. J. Neurosci. 1998, 18, 10457-10463. [CrossRef] [PubMed]

42. Nguyen, D.; Stangel, M. Expression of the chemokine receptors CXCR1 and CXCR2 in rat oligodendroglial cells. Brain Res. Dev. Brain Res. 2001, 128,77-81. [CrossRef]

43. Padovani-Claudio, D.A.; Liu, L.; Ransohoff, R.M.; Miller, R.H. Alterations in the oligodendrocyte lineage, myelin, and white matter in adult mice lacking the chemokine receptor CXCR2. Glia 2006, 54, 471-483. [CrossRef] [PubMed]

44. Tirotta, E.; Ransohoff, R.M.; Lane, T.E. CXCR2 signaling protects oligodendrocyte progenitor cells from IFN- $\gamma /$ CXCL10-mediated apoptosis. Glia 2011, 59, 1518-1528. [CrossRef] [PubMed]

45. Tsai, H.-H.; Frost, E.; To, V.; Robinson, S.; ffrench-Constant, C.; Geertman, R.; Ransohoff, R.M.; Miller, R.H. The Chemokine Receptor CXCR2 Controls Positioning of Oligodendrocyte Precursors in Developing Spinal Cord by Arresting Their Migration. Cell 2002, 110, 373-383. [CrossRef]

46. Li, M.; Ransohoff, R.M. Multiple roles of chemokine CXCL12 in the central nervous system: a migration from immunology to neurobiology. Prog. Neurobiol. 2008, 84, 116-131. [CrossRef] [PubMed]

47. Lavi, E.; Strizki, J.M.; Ulrich, A.M.; Zhang, W.; Fu, L.; Wang, Q.; O'Connor, M.; Hoxie, J.A.; González-Scarano, F. CXCR-4 (Fusin), a co-receptor for the type 1 human immunodeficiency virus (HIV-1), is expressed in the human brain in a variety of cell types, including microglia and neurons. Am. J. Pathol. 1997, 151, 1035-1042. [PubMed]

48. McGrath, K.E.; Koniski, A.D.; Maltby, K.M.; McGann, J.K.; Palis, J. Embryonic Expression and Function of the Chemokine SDF-1 and Its Receptor, CXCR4. Dev. Biol. 1999, 213, 442-456. [CrossRef] [PubMed]

49. Ma, Q.; Jones, D.; Borghesani, P.R.; Segal, R.A.; Nagasawa, T.; Kishimoto, T.; Bronson, R.T.; Springer, T.A. Impaired B-lymphopoiesis, myelopoiesis, and derailed cerebellar neuron migration in CXCR4- and SDF-1-deficient mice. Proc. Natl. Acad. Sci. USA 1998, 95, 9448-9453. [CrossRef] [PubMed]

50. Dziembowska, M.; Tham, T.N.; Lau, P.; Vitry, S.; Lazarini, F.; Dubois-Dalcq, M.; Lau, P. A Role for CXCR4 Signaling in Survival and Migration of Neural and Oligodendrocyte Precursors. Glia 2005, 50, 258-269. [CrossRef] [PubMed]

51. Kadi, L.; Selvaraju, R.; de Lys, P.; Proudfoot, A.E.I.; Wells, T.N.C.; Boschert, U. Differential effects of chemokines on oligodendrocyte precursor proliferation and myelin formation in vitro. J. Neuroimmunol. 2006, 174, 133-146. [CrossRef] [PubMed]

52. Miller, R.H.; David, S.; Patel, R.; Abney, E.R.; Raff, M.C. A quantitative immunohistochemical study of macroglial cell development in the rat optic nerve: in vivo evidence for two distinct astrocyte lineages. Dev. Biol. 1985, 111, 35-41. [CrossRef]

53. Hill, R.A.; Patel, K.D.; Medved, J.; Reiss, A.M.; Nishiyama, A. NG2 cells in white matter but not gray matter proliferate in response to PDGF. J. Neurosci. 2013, 33, 14558-14566. [CrossRef] [PubMed]

54. Young, K.M.; Psachoulia, K.; Tripathi, R.B.; Dunn, S.-J.; Cossell, L.; Attwell, D.; Tohyama, K.; Richardson, W.D. Oligodendrocyte dynamics in the healthy adult CNS: evidence for myelin remodeling. Neuron 2013, 77, 873-885. [CrossRef] [PubMed]

55. Rivers, L.E.; Young, K.M.; Rizzi, M.; Jamen, F.; Psachoulia, K.; Wade, A.; Kessaris, N.; Richardson, W.D. PDGFRA/NG2 glia generate myelinating oligodendrocytes and piriform projection neurons in adult mice. Nat. Neurosci. 2008, 11, 1392-1401. [CrossRef] [PubMed] 
56. Accetta, R.; Damiano, S.; Morano, A.; Mondola, P.; Paternò, R.; Avvedimento, E.V.; Santillo, M. Reactive Oxygen Species Derived from NOX3 and NOX5 Drive Differentiation of Human Oligodendrocytes. Front. Cell. Neurosci. 2016, 10, 146. [CrossRef] [PubMed]

57. Noble, M.; Smith, J.; Ladi, E.; Mayer-Proschel, M. Redox state is a central modulator of the balance between self-renewal and differentiation in a dividing glial precursor cell. Proc. Natl. Acad. Sci. USA 2000, 97, 10032-10037. [CrossRef]

58. Clarke, L.E.; Young, K.M.; Hamilton, N.B.; Li, H.; Richardson, W.D.; Attwell, D. Properties and fate of oligodendrocyte progenitor cells in the corpus callosum, motor cortex, and piriform cortex of the mouse. J. Neurosci. 2012, 32, 8173-8185. [CrossRef] [PubMed]

59. Noble, M.; Murray, K. Purified astrocytes promote the in vitro division of a bipotential glial progenitor cell. EMBO J. 1984, 3, 2243-2247. [PubMed]

60. Raff, M.C.; Lillien, L.E.; Richardson, W.D.; Burne, J.F.; Noble, M.D. Platelet-derived growth factor from astrocytes drives the clock that times oligodendrocyte development in culture. Nature 1988, 333, 562-565. [CrossRef] [PubMed]

61. Hu, J.-G.; Fu, S.-L.; Wang, Y.-X.; Li, Y.; Jiang, X.-Y.; Wang, X.-F.; Qiu, M.-S.; Lu, P.-H.; Xu, X.-M. Platelet-derived growth factor-AA mediates oligodendrocyte lineage differentiation through activation of extracellular signal-regulated kinase signaling pathway. Neuroscience 2008, 151, 138-147. [CrossRef] [PubMed]

62. Barateiro, A.; Fernandes, A. Temporal oligodendrocyte lineage progression: In vitro models of proliferation, differentiation and myelination. Biochim. Biophys. Acta - Mol. Cell Res. 2014, 1843, 1917-1929. [CrossRef] [PubMed]

63. McKinnon, R.D.; Matsui, T.; Dubois-Dalcq, M.; Aaronson, S.A. FGF modulates the PDGF-driven pathway of oligodendrocyte development. Neuron 1990, 5, 603-614. [CrossRef]

64. Raff, M.C.; Miller, R.H.; Noble, M. A glial progenitor cell that develops in vitro into an astrocyte or an oligodendrocyte depending on culture medium. Nature 1983, 303, 390-396. [CrossRef] [PubMed]

65. Soriano, P. The PDGF alpha receptor is required for neural crest cell development and for normal patterning of the somites. Development 1997, 124, 2691-2700. [PubMed]

66. Fruttiger, M.; Karlsson, L.; Hall, A.C.; Abramsson, A.; Calver, A.R.; Bostrom, H.; Willetts, K.; Bertold, C.H.; Heath, J.K.; Betsholtz, C.; et al. Defective oligodendrocyte development and severe hypomyelination in PDGF-A knockout mice. Development 1999, 126, 457-467. [PubMed]

67. Calver, A.R.; Hall, A.C.; Yu, W.-P.; Walsh, F.S.; Heath, J.K.; Betsholtz, C.; Richardson, W.D. Oligodendrocyte Population Dynamics and the Role of PDGF In Vivo. Neuron 1998, 20, 869-882. [CrossRef]

68. Hu, J.-G.; Wang, X.-F.; Deng, L.-X.; Liu, N.-K.; Gao, X.; Chen, J.; Zhou, F.C.; Xu, X.-M. Cotransplantation of Glial Restricted Precursor Cells and Schwann Cells Promotes Functional Recovery after Spinal Cord Injury. Cell Transplant. 2013, 22, 2219-2236. [CrossRef] [PubMed]

69. McKinnon, R.D.; Matsui, T.; Aranda, M.; Dubois-Dalcq, M. A Role for Fibroblast Growth Factor in Oligodendrocyte Development. Ann. N. Y. Acad. Sci. 1991, 638, 378-386. [CrossRef] [PubMed]

70. Gard, A.L.; Pfeiffer, S.E. Glial Cell Mitogens bFGF and PDGF Differentially Regulate Development of O4+GalC- Oligodendrocyte Progenitors. Dev. Biol. 1993, 159, 618-630. [CrossRef] [PubMed]

71. Bögler, O.; Wren, D.; Barnett, S.C.; Land, H.; Noble, M. Cooperation between two growth factors promotes extended self-renewal and inhibits differentiation of oligodendrocyte-type-2 astrocyte (O-2A) progenitor cells. Proc. Natl. Acad. Sci. USA 1990, 87, 6368-6372. [CrossRef] [PubMed]

72. Eccleston, P.A.; Silberberg, D.H. Fibroblast growth factor is a mitogen for oligodendrocytes in vitro. Brain Res. 1985, 353, 315-318. [CrossRef]

73. Vaccarino, F.M.; Schwartz, M.L.; Raballo, R.; Nilsen, J.; Rhee, J.; Zhou, M.; Doetschman, T.; Coffin, J.D.; Wyland, J.J.; Hung, Y.-T.E. Erratum: Changes in cerebral cortex size are governed by fibroblast growth factor during embryogenesis. Nat. Neurosci. 1999, 2, 246-253. [CrossRef] [PubMed]

74. Murtie, J.C.; Zhou, Y.-X.; Le, T.Q.; Armstrong, R.C. In vivo analysis of oligodendrocyte lineage development in postnatal FGF2 null mice. Glia 2005, 49, 542-554. [CrossRef] [PubMed]

75. Bansal, R.; Kumar, M.; Murray, K.; Morrison, R.S.; Pfeiffer, S.E. Regulation of FGF Receptors in the Oligodendrocyte Lineage. Mol. Cell. Neurosci. 1996, 7, 263-275. [CrossRef] [PubMed]

76. Fortin, D.; Rom, E.; Sun, H.; Yayon, A.; Bansal, R. Distinct Fibroblast Growth Factor (FGF)/FGF Receptor Signaling Pairs Initiate Diverse Cellular Responses in the Oligodendrocyte Lineage. J. Neurosci. 2005, 25, 7470-7479. [CrossRef] [PubMed] 
77. Zhou, Y.-X.; Flint, N.C.; Murtie, J.C.; Le, T.Q.; Armstrong, R.C. Retroviral lineage analysis of fibroblast growth factor receptor signaling in FGF2 inhibition of oligodendrocyte progenitor differentiation. Glia 2006, 54, 578-590. [CrossRef] [PubMed]

78. Goddard, D.R.; Berry, M.; Kirvell, S.L.; Butt, A.M. Fibroblast Growth Factor-2 Inhibits Myelin Production by Oligodendrocytes in Vivo. Mol. Cell. Neurosci. 2001, 18, 557-569. [CrossRef] [PubMed]

79. Fressinaud, C.; Vallat, J.M.; Labourdette, G. Basic fibroblast growth factor down-regulates myelin basic protein gene expression and alters myelin compaction of mature oligodendrocytes in vitro. J. Neurosci. Res. 1995, 40, 285-293. [CrossRef] [PubMed]

80. Wang, Z.; Colognato, H.; ffrench-Constant, C. Contrasting effects of mitogenic growth factors on myelination in neuron-oligodendrocyte co-cultures. Glia 2007, 55, 537-545. [CrossRef] [PubMed]

81. Jiang, F.; Frederick, T.J.; Wood, T.L. IGF-I Synergizes with FGF-2 to Stimulate Oligodendrocyte Progenitor Entry into the Cell Cycle. Dev. Biol. 2001, 232, 414-423. [CrossRef] [PubMed]

82. Shemer, J.; Raizada, M.K.; Masters, B.A.; Ota, A.; Leroith, D. Insulin-like Growth Factor I Receptors in Neuronal and Glial Cells CHARACTERIZATION AND BIOLOGICAL EFFECTS IN PRIMARY CULTURE*. J. Biol. Chem. 1987, 262, 7693-7699. [PubMed]

83. Jones, J.I.; Clemmons, D.R. Insulin-Like Growth Factors and Their Binding Proteins: Biological Actions*. Endocr. Rev. 1995, 16, 3-34. [CrossRef] [PubMed]

84. McMorris, F.A.; Smith, T.M.; DeSalvo, S.; Furlanetto, R.W. Insulin-like growth factor I/somatomedin C: a potent inducer of oligodendrocyte development. Proc. Natl. Acad. Sci. USA 1986, 83, 822-826. [CrossRef] [PubMed]

85. McMorris, F.A.; Dubois-Dalcq, M. Insulin-like growth factor I promotes cell proliferation and oligodendroglial commitment in rat glial progenitor cells developing in vitro. J. Neurosci. Res. 1988, 21, 199-209. [CrossRef] [PubMed]

86. Popken, G.J.; Hodge, R.D.; Ye, P.; Zhang, J.; Ng, W.; O’Kusky, J.R.; D’Ercole, A.J. In vivo effects of insulinlike growth factor-I (IGF-I) on prenatal and early postnatal development of the central nervous system. Eur. J. Neurosci. 2004, 19, 2056-2068. [CrossRef] [PubMed]

87. Hodge, R.D.; D'Ercole, A.J.; O'Kusky, J.R. Insulin-like growth factor-I accelerates the cell cycle by decreasing G1 phase length and increases cell cycle reentry in the embryonic cerebral cortex. J. Neurosci. 2004, 24, 10201-10210. [CrossRef] [PubMed]

88. Frederick, T.J.; Min, J.; Altieri, S.C.; Mitchell, N.E.; Wood, T.L. Synergistic induction of cyclin D1 in oligodendrocyte progenitor cells by IGF-I and FGF-2 requires differential stimulation of multiple signaling pathways. Glia 2007, 55, 1011-1022. [CrossRef] [PubMed]

89. Cui, Q.-L.; Almazan, G. IGF-I-induced oligodendrocyte progenitor proliferation requires PI3K/Akt, MEK/ERK, and Src-like tyrosine kinases. J. Neurochem. 2007, 100, 1480-1493. [CrossRef] [PubMed]

90. Palacios, N.; Sanchez-Franco, F.; Fernandez, M.; Sanchez, I.; Cacicedo, L. Intracellular events mediating insulin-like growth factor I-induced oligodendrocyte development: modulation by cyclic AMP. J. Neurochem. 2005, 95, 1091-1107. [CrossRef] [PubMed]

91. Frederick, T.J.; Wood, T.L. IGF-I and FGF-2 coordinately enhance cyclin D1 and cyclin E-cdk2 association and activity to promote G1 progression in oligodendrocyte progenitor cells. Mol. Cell. Neurosci. 2004, 25, 480-492. [CrossRef] [PubMed]

92. Mairet-Coello, G.; Tury, A.; DiCicco-Bloom, E. Insulin-like growth factor-1 promotes G(1)/S cell cycle progression through bidirectional regulation of cyclins and cyclin-dependent kinase inhibitors via the phosphatidylinositol 3-kinase/Akt pathway in developing rat cerebral cortex. J. Neurosci. 2009, 29, 775-788. [CrossRef] [PubMed]

93. Barres, B.A.; Hart, I.K.; Coles, H.S.R.; Burne, J.F.; Voyvodic, J.T.; Richardson, W.D.; Raff, M.C. Cell death in the oligodendrocyte lineage. J. Neurobiol. 1992, 23, 1221-1230. [CrossRef] [PubMed]

94. Barres, B.A.; Schmid, R.; Sendnter, M.; Raff, M.C. Multiple extracellular signals are required for long-term oligodendrocyte survival. Development 1993, 118, 283-295. [PubMed]

95. Pang, Y.; Zheng, B.; Fan, L.-W.; Rhodes, P.G.; Cai, Z. IGF-1 protects oligodendrocyte progenitors against $\mathrm{TNF} \alpha$-induced damage by activation of PI3K/Akt and interruption of the mitochondrial apoptotic pathway. Glia 2007, 55, 1099-1107. [CrossRef] [PubMed]

96. Chao, M.V. The p75 neurotrophin receptor. J. Neurobiol. 1994, 25, 1373-1385. [CrossRef] [PubMed] 
97. Huang, E.J.; Reichardt, L.F. Trk Receptors: Roles in Neuronal Signal Transduction. Annu. Rev. Biochem. 2003, 72, 609-642. [CrossRef] [PubMed]

98. Xiao, J.; Kilpatrick, T.J.; Murray, S.S. The Role of Neurotrophins in the Regulation of Myelin Development. Neurosignals 2009, 17, 265-276. [CrossRef] [PubMed]

99. Barbacid, M. Neurotrophic factors and their receptors. Curr. Opin. Cell Biol. 1995, 7, 148-155. [CrossRef]

100. Chao, M.V.; Hempstead, B.L. p75 and Trk: a two-receptor system. Trends Neurosci. 1995, 18, $321-326$. [CrossRef]

101. Van't Veer, A.; Du, Y.; Fischer, T.Z.; Boetig, D.R.; Wood, M.R.; Dreyfus, C.F. Brain-derived neurotrophic factor effects on oligodendrocyte progenitors of the basal forebrain are mediated through trkB and the MAP kinase pathway. J. Neurosci. Res. 2009, 87, 69-78. [CrossRef] [PubMed]

102. Du, Y.; Fischer, T.Z.; Clinton-Luke, P.; Lercher, L.D.; Dreyfus, C.F. Distinct effects of p75 in mediating actions of neurotrophins on basal forebrain oligodendrocytes. Mol. Cell. Neurosci. 2006, 31, 366-375. [CrossRef] [PubMed]

103. Johnson, J.R.; Chu, A.K.; Sato-Bigbee, C. Possible role of CREB in the stimulation of oligodendrocyte precursor cell proliferation by neurotrophin-3. J. Neurochem. 2000, 74, 1409-1417. [CrossRef] [PubMed]

104. Barres, B.A.; Raff, M.C.; Gaese, F.; Bartke, I.; Dechant, G.; Barde, Y.-A. A crucial role for neurotrophin-3 in oligodendrocyte development. Nature 1994, 367, 371-375. [CrossRef] [PubMed]

105. Kahn, M.A.; Kumar, S.; Liebl, D.; Chang, R.; Parada, L.F.; De Vellis, J. Mice lacking NT-3, and its receptor TrkC, exhibit profound deficiencies in CNS glial cells. Glia 1999, 26, 153-165. [CrossRef]

106. Olguín-Albuerne, M.; Morán, J. Redox Signaling Mechanisms in Nervous System Development. Antioxid. Redox Signal. 2018, 28, 1603-1625. [CrossRef] [PubMed]

107. Caillava, C.; Baron-Van Evercooren, A. Differential requirement of cyclin-dependent kinase 2 for oligodendrocyte progenitor cell proliferation and differentiation. Cell Div. 2012, 7, 14. [CrossRef] [PubMed]

108. Belachew, S.; Aguirre, A.A.; Wang, H.; Vautier, F.; Yuan, X.; Anderson, S.; Kirby, M.; Gallo, V. Cyclindependent kinase-2 controls oligodendrocyte progenitor cell cycle progression and is downregulated in adult oligodendrocyte progenitors. J. Neurosci. 2002, 22, 8553-8562. [CrossRef] [PubMed]

109. Sherr, C.J.; Roberts, J.M. Inhibitors of mammalian G1 cyclin-dependent kinases. Genes Dev. 1995, 9, 1149-1163. [CrossRef] [PubMed]

110. Jones, S.A.; Jolson, D.M.; Cuta, K.K.; Mariash, C.N.; Anderson, G.W. Triiodothyronine is a survival factor for developing oligodendrocytes. Mol. Cell. Endocrinol. 2003, 199, 49-60. [CrossRef]

111. Ahlgren, S.C.; Wallace, H.; Bishop, J.; Neophytou, C.; Raff, M.C. Effects of Thyroid Hormone on Embryonic Oligodendrocyte Precursor Cell Development in Vivo and in Vitro. Mol. Cell. Neurosci. 1997, 9, 420-432. [CrossRef] [PubMed]

112. Gao, F.-B.; Apperly, J.; Raff, M. Cell-Intrinsic Timers and Thyroid Hormone Regulate the Probability of Cell-Cycle Withdrawal and Differentiation of Oligodendrocyte Precursor Cells. Dev. Biol. 1998, 197, 54-66. [CrossRef] [PubMed]

113. Barres, B.A.; Lazar, M.A.; Raff, M.C. A novel role for thyroid hormone, glucocorticoids and retinoic acid in timing oligodendrocyte development. Development 1994, 120, 1097-1108. [PubMed]

114. Sarliève, L.L.; Rodríguez-Peña, A.; Langley, K. Expression of Thyroid Hormone Receptor Isoforms in the Oligodendrocyte Lineage. Neurochem. Res. 2003, 29, 903-922. [CrossRef]

115. Baas, D.; Fressinaud, C.; Ittel, M.E.; Reeber, A.; Dalençon, D.; Puymirat, J.; Sarliève, L.L. Expression of thyroid hormone receptor isoforms in rat oligodendrocyte cultures. Effect of 3,5,3'-triiodo-1-thyronine. Neurosci. Lett. 1994, 176, 47-51. [CrossRef]

116. Carré, J.-L.; Demerens, C.; Rodríguez-Peñ, A.; Floch, H.H.; Vincendon, G.; Sarliève, L.L. Thyroid Hormone Receptor Isoforms Are Sequentially Expressed in Oligodendrocyte Lineage Cells During Rat Cerebral Development. J. Neurosci. Res 1998, 54, 584-594. [CrossRef]

117. Almazan, G.; Honegger, P.; Matthieu, J.M. Triiodothyronine stimulation of oligodendroglial differentiation and myelination. A developmental study. Dev. Neurosci. 1985, 7, 45-54. [CrossRef] [PubMed]

118. Baas, D.; Bourbeau, D.; Sarli Ve, L.L.; Ittel, M.-E.; Dussault, J.H.; Puymirat, J. Oligodendrocyte Maturation and Progenitor Cell Proliferation Are Independently Regulated by Thyroid Hormone. Glia 1997, 19, $324-332$. [CrossRef]

119. Almeida, R.; Lyons, D. Oligodendrocyte Development in the Absence of Their Target Axons In Vivo. PLoS ONE 2016, 11, e0164432. [CrossRef] [PubMed] 
120. Beck, K.D.; Powell-Braxton, L.; Widmer, H.R.; Valverde, J.; Hefti, F. Igf1 gene disruption results in reduced brain size, CNS hypomyelination, and loss of hippocampal granule and striatal parvalbumin-containing neurons. Neuron 1995, 14, 717-730. [CrossRef]

121. Zeger, M.; Popken, G.; Zhang, J.; Xuan, S.; Lu, Q.R.; Schwab, M.H.; Nave, K.-A.; Rowitch, D.; D’Ercole, A.J.; Ye, P. Insulin-like growth factor type 1 receptor signaling in the cells of oligodendrocyte lineage is required for normalin vivo oligodendrocyte development and myelination. Glia 2007, 55, 400-411. [CrossRef] [PubMed]

122. Carson, M.J.; Behringer, R.R.; Brinster, R.L.; McMorris, F.A. Insulin-like growth factor I increases brain growth and central nervous system myelination in transgenic mice. Neuron 1993, 10, 729-740. [CrossRef]

123. Ye, P.; Carson, J.; D'Ercole, A.J. In vivo actions of insulin-like growth factor-I (IGF-I) on brain myelination: studies of IGF-I and IGF binding protein-1 (IGFBP-1) transgenic mice. J. Neurosci. 1995, 15, 7344-7356. [CrossRef] [PubMed]

124. Mozell, R.L.; McMorris, F.A. Insulin-like growth factor I stimulates oligodendrocyte development and myelination in rat brain aggregate cultures. J. Neurosci. Res. 1991, 30, 382-390. [CrossRef] [PubMed]

125. Luzi, P.; Zaka, M.; Rao, H.Z.; Curtis, M.; Rafi, M.A.; Wenger, D.A. Generation of transgenic mice expressing insulin-like growth factor-1 under the control of the myelin basic protein promoter: increased myelination and potential for studies on the effects of increased IGF-1 on experimentally and genetically induced demyelination. Neurochem. Res. 2004, 29, 881-889. [PubMed]

126. Adler, R.; Landa, K.B.; Manthorpe, M.; Varon, S. Cholinergic neuronotrophic factors: intraocular distribution of trophic activity for ciliary neurons. Science 1979, 204, 1434-1436. [CrossRef] [PubMed]

127. Stöckli, K.A.; Lillien, L.E.; Näher-Noé, M.; Breitfeld, G.; Hughes, R.A.; Raff, M.C.; Thoenen, H.; Sendtner, M. Regional Distribution, Developmental Changes, and Cellular Localization of CNTF-mRNA and Protein in the Rat Brain. J. Cell Biol. 1991, 115, 447-459. [CrossRef] [PubMed]

128. Barres, B.A.; Burne, J.F.; Holtmann, B.; Thoenen, H.; Sendtner, M.; Raff, M.C. Ciliary Neurotrophic Factor Enhances the Rate of Oligodendrocyte Generation. Mol. Cell. Neurosci. 1996, 8, 146-156. [CrossRef] [PubMed]

129. Marmur, R.; Kessler, J.A.; Zhu, G.; Gokhan, S.; Mehler, M.F. Differentiation of oligodendroglial progenitors derived from cortical multipotent cells requires extrinsic signals including activation of gp130/LIFbeta receptors. J. Neurosci. 1998, 18, 9800-9811. [CrossRef] [PubMed]

130. Stankoff, B.; Aigrot, M.-S.; Noël, F.; Wattilliaux, A.; Zalc, B.; Lubetzki, C. Ciliary neurotrophic factor (CNTF) enhances myelin formation: A novel role for CNTF and CNTF-related molecules. J. Neurosci. 2002, 22, 9221-9227. [CrossRef] [PubMed]

131. Ibarrola, N.; Mayer-Pröschel, M.; Rodriguez-Peña, A.; Noble, M. Evidence for the Existence of at Least Two Timing Mechanisms That Contribute to Oligodendrocyte Generationin Vitro. Dev. Biol. 1996, 180, 1-21. [CrossRef] [PubMed]

132. Mayer, M.; Bhakoo, K.; Noble, M. Ciliary neurotrophic factor and leukemia inhibitory factor promote the generation, maturation and survival of oligodendrocytes in vitro. Development 1994, 120, 143-153. [PubMed]

133. Salehi, Z.; Hadiyan, S.P.; Navidi, R. Ciliary Neurotrophic Factor Role in Myelin Oligodendrocyte Glycoprotein Expression in Cuprizone-Induced Multiple Sclerosis Mice. Cell. Mol. Neurobiol. 2013, 33, 531-535. [CrossRef] [PubMed]

134. Linker, R.A.; Mäurer, M.; Gaupp, S.; Martini, R.; Holtmann, B.; Giess, R.; Rieckmann, P.; Lassmann, H.; Toyka, K.V.; Sendtner, M.; et al. CNTF is a major protective factor in demyelinating CNS disease: A neurotrophic cytokine as modulator in neuroinflammation. Nat. Med. 2002, 8, 620-624. [CrossRef] [PubMed]

135. Ernfors, P.; Ibáñez, C.F.; Ebendal, T.; Olson, L.; Persson, H. Molecular cloning and neurotrophic activities of a protein with structural similarities to nerve growth factor: developmental and topographical expression in the brain. Proc. Natl. Acad. Sci. USA 1990, 87, 5454-5458. [CrossRef] [PubMed]

136. Heinrich, M.; Gorath, M.; Richter-Landsberg, C. Neurotrophin-3 (NT-3) Modulates Early Differentiation of Oligodendrocytes in Rat Brain Cortical Cultures. Glia 1999, 28, 244-255. [CrossRef]

137. Rubio, N.; Rodriguez, R.; Arevalo, M.A. In vitro myelination by oligodendrocyte precursor cells transfected with the neurotrophin-3 gene. Glia 2004, 47, 78-87. [CrossRef] [PubMed]

138. Du, Y.; Lercher, L.D.; Zhou, R.; Dreyfus, C.F. Mitogen-activated protein kinase pathway mediates effects of brain-derived neurotrophic factor on differentiation of basal forebrain oligodendrocytes. J. Neurosci. Res. 2006, 84, 1692-1702. [CrossRef] [PubMed] 
139. Xiao, J.; Wong, A.W.; Willingham, M.M.; van den Buuse, M.; Kilpatrick, T.J.; Murray, S.S. Brain-Derived Neurotrophic Factor Promotes Central Nervous System Myelination via a Direct Effect upon Oligodendrocytes. Neurosignals 2010, 18, 186-202. [CrossRef] [PubMed]

140. Cosgaya, J.M.; Chan, J.R.; Shooter, E.M. The Neurotrophin Receptor p75NTR as a Positive Modulator of Myelination. Science 2002, 298, 1245-1248. [CrossRef] [PubMed]

141. Cellerino, A.; Carroll, P.; Thoenen, H.; Barde, Y.-A. Reduced Size of Retinal Ganglion Cell Axons and Hypomyelination in Mice Lacking Brain-Derived Neurotrophic Factor. Mol. Cell. Neurosci. 1997, 9, 397-408. [CrossRef] [PubMed]

142. Djalali, S.; Holtje, M.; Grosse, G.; Rothe, T.; Stroh, T.; Grosse, J.; Deng, D.R.; Hellweg, R.; Grantyn, R.; Hortnagl, H.; et al. Effects of brain-derived neurotrophic factor (BDNF) on glial cells and serotonergic neurones during development. J. Neurochem. 2005, 92, 616-627. [CrossRef] [PubMed]

143. Vondran, M.W.; Clinton-Luke, P.; Honeywell, J.Z.; Dreyfus, C.F. BDNF+/- mice exhibit deficits in oligodendrocyte lineage cells of the basal forebrain. Glia 2010, 58, 848-856. [CrossRef] [PubMed]

144. Wong, A.W.; Xiao, J.; Kemper, D.; Kilpatrick, T.J.; Murray, S.S. Oligodendroglial expression of TrkB independently regulates myelination and progenitor cell proliferation. J. Neurosci. 2013, 33, 4947-4957. [CrossRef] [PubMed]

145. Du, Y.; Fischer, T.Z.; Lee, L.N.; Lercher, L.D.; Dreyfus, C.F. Regionally Specific Effects of BDNF on Oligodendrocytes. Dev. Neurosci. 2003, 25, 116-126. [CrossRef] [PubMed]

146. Mei, L.; Nave, K.-A. Neuregulin-ERBB signaling in the nervous system and neuropsychiatric diseases. Neuron 2014, 83, 27-49. [CrossRef] [PubMed]

147. Canoll, P.D.; Kraemer, R.; Teng, K.K.; Marchionni, M.A.; Salzer, J.L. GGF/Neuregulin Induces a Phenotypic Reversion of Oligodendrocytes. Mol. Cell. Neurosci. 1999, 13, 79-94. [CrossRef] [PubMed]

148. Gauthier, M.-K.; Kosciuczyk, K.; Tapley, L.; Karimi-Abdolrezaee, S. Dysregulation of the neuregulin-1-ErbB network modulates endogenous oligodendrocyte differentiation and preservation after spinal cord injury. Eur. J. Neurosci. 2013, 38, 2693-2715. [CrossRef] [PubMed]

149. Flores, A.I.; Mallon, B.S.; Matsui, T.; Ogawa, W.; Rosenzweig, A.; Okamoto, T.; Macklin, W.B. Akt-mediated survival of oligodendrocytes induced by neuregulins. J. Neurosci. 2000, 20, 7622-7630. [CrossRef] [PubMed]

150. Fernandez, P.A.; Tang, D.G.; Cheng, L.; Prochiantz, A.; Mudge, A.W.; Raff, M.C. Evidence that axon-derived neuregulin promotes oligodendrocyte survival in the developing rat optic nerve. Neuron 2000, 28, 81-90. [CrossRef]

151. Colognato, H.; Baron, W.; Avellana-Adalid, V.; Relvas, J.B.; Evercooren, A.B.-V.; Georges-Labouesse, E.; ffrench-Constant, C. CNS integrins switch growth factor signalling to promote target-dependent survival. Nat. Cell Biol. 2002, 4, 833-841. [CrossRef] [PubMed]

152. Colognato, H.; Ramachandrappa, S.; Olsen, I.M.; ffrench-Constant, C. Integrins direct Src family kinases to regulate distinct phases of oligodendrocyte development. J. Cell Biol. 2004, 167, 365-375. [CrossRef] [PubMed]

153. Kim, J.Y.; Sun, Q.; Oglesbee, M.; Yoon, S.O. The role of ErbB2 signaling in the onset of terminal differentiation of oligodendrocytes in vivo. J. Neurosci. 2003, 23, 5561-5571. [CrossRef] [PubMed]

154. Roy, K.; Murtie, J.C.; El-Khodor, B.F.; Edgar, N.; Sardi, S.P.; Hooks, B.M.; Benoit-Marand, M.; Chen, C.; Moore, H.; O’Donnell, P.; Brunner, D.; Corfas, G. Loss of erbB signaling in oligodendrocytes alters myelin and dopaminergic function, a potential mechanism for neuropsychiatric disorders. Proc. Natl. Acad. Sci. USA 2007, 104, 8131-8136. [CrossRef] [PubMed]

155. Park, S.K.; Miller, R.; Krane, I.; Vartanian, T. The erbB2 gene is required for the development of terminally differentiated spinal cord oligodendrocytes. J. Cell Biol. 2001, 154, 1245-1258. [CrossRef] [PubMed]

156. Küspert, M.; Wegner, M. SomethiNG 2 talk about-Transcriptional regulation in embryonic and adult oligodendrocyte precursors. Brain Res. 2016, 1638, 167-182. [CrossRef] [PubMed]

157. Traiffort, E.; Zakaria, M.; Laouarem, Y.; Ferent, J. Hedgehog: A Key Signaling in the Development of the Oligodendrocyte Lineage. J. Dev. Biol. 2016, 4, 28. [CrossRef] [PubMed]

158. Crowe, M.J.; Bresnahan, J.C.; Shuman, S.L.; Masters, J.N.; Crowe, M.S. Apoptosis and delayed degeneration after spinal cord injury in rats and monkeys. Nat. Med. 1997, 3, 73-76. [CrossRef] [PubMed]

159. Lytle, J.M.; Vicini, S.; Wrathall, J.R. Phenotypic changes in NG2+ cells after spinal cord injury. J. Neurotrauma 2006, 23, 1726-1738. [CrossRef] [PubMed] 
160. Grossman, S.D.; Rosenberg, L.J.; Wrathall, J.R. Temporal-spatial pattern of acute neuronal and glial loss after spinal cord contusion. Exp. Neurol. 2001. [CrossRef] [PubMed]

161. McTigue, D.M.; Wei, P.; Stokes, B.T. Proliferation of NG2-positive cells and altered oligodendrocyte numbers in the contused rat spinal cord. J. Neurosci. 2001, 21, 3392-3400. [CrossRef] [PubMed]

162. Lotocki, G.; de Rivero Vaccari, J.; Alonso, O.; Molano, J.S.; Nixon, R.; Dietrich, W.D.; Bramlett, H.M. Oligodendrocyte Vulnerability Following Traumatic Brain Injury in Rats: Effect of Moderate Hypothermia. Ther. Hypothermia Temp. Manag. 2011, 1, 43-51. [CrossRef] [PubMed]

163. Gensert, J.M.; Goldman, J.E. Endogenous progenitors remyelinate demyelinated axons in the adult CNS. Neuron 1997, 19, 197-203. [CrossRef]

164. Hesp, Z.C.; Goldstein, E.Z.; Goldstein, E.A.; Miranda, C.J.; Kaspar, B.K.; Kaspar, B.K.; McTigue, D.M. Chronic oligodendrogenesis and remyelination after spinal cord injury in mice and rats. J. Neurosci. 2015, 35, 1274-1290. [CrossRef] [PubMed]

165. Sellers, D.L.; Maris, D.O.; Horner, P.J. Postinjury Niches Induce Temporal Shifts in Progenitor Fates to Direct Lesion Repair after Spinal Cord Injury. J. Neurosci. 2009, 29, 6722-6733. [CrossRef] [PubMed]

166. Zai, L.J.; Wrathall, J.R. Cell proliferation and replacement following contusive spinal cord injury. Glia 2005, 50, 247-257. [CrossRef] [PubMed]

167. Barnabé-Heider, F.; Göritz, C.; Sabelström, H.; Takebayashi, H.; Pfrieger, F.W.; Meletis, K.; Frisén, J. Origin of New Glial Cells in Intact and Injured Adult Spinal Cord. Cell Stem Cell 2010, 7, 470-482. [CrossRef] [PubMed]

168. Meletis, K.; Barnabé-Heider, F.; Carlén, M.; Evergren, E.; Tomilin, N.; Shupliakov, O.; Frisén, J. Spinal cord injury reveals multilineage differentiation of ependymal cells. PLoS Biol. 2008, 6, e182. [CrossRef] [PubMed]

169. Karimi-Abdolrezaee, S.; Billakanti, R. Reactive Astrogliosis after Spinal Cord Injury-Beneficial and Detrimental Effects. Mol. Neurobiol. 2012, 46, 251-264. [CrossRef] [PubMed]

170. Lacroix, S.; Hamilton, L.K.; Vaugeois, A.; Beaudoin, S.; Breault-Dugas, C.; Pineau, I.; Lévesque, S.A.; Grégoire, C.-A.; Fernandes, K.J.L. Central Canal Ependymal Cells Proliferate Extensively in Response to Traumatic Spinal Cord Injury but Not Demyelinating Lesions. PLoS ONE 2014, 9, e85916. [CrossRef] [PubMed]

171. BUNGE, M.B.; BUNGE, R.P.; RIS, H. Ultrastructural study of remyelination in an experimental lesion in adult cat spinal cord. J. Biophys. Biochem. Cytol. 1961, 10, 67-94. [CrossRef] [PubMed]

172. Gledhill, R.F.; Harrison, B.M.; McDonald, W.I. Demyelination and Remyelination after Acute Spinal Cord Compression. Exp. Neurol. 1973, 38, 472-487. [CrossRef]

173. Rasminsky, M.; Sears, T.A. Internodal conduction in undissected demyelinated nerve fibres. J. Physiol. 1972, 227, 323-350. [CrossRef] [PubMed]

174. Mcdonald, W.I. Pathophysiology in multiple sclerosis. Brain 1974, 97, 179-196. [CrossRef] [PubMed]

175. Wrathall, J.R.; Li, W.; Hudson, L.D. Myelin gene expression after experimental contusive spinal cord injury. J. Neurosci. 1998, 18, 8780-8793. [CrossRef] [PubMed]

176. Totoiu, M.O.; Keirstead, H.S. Spinal cord injury is accompanied by chronic progressive demyelination. J. Comp. Neurol. 2005, 486, 373-383. [CrossRef] [PubMed]

177. Guest, J.D.; Hiester, E.D.; Bunge, R.P. Demyelination and Schwann cell responses adjacent to injury epicenter cavities following chronic human spinal cord injury. Exp. Neurol. 2005, 192, 384-393. [CrossRef] [PubMed]

178. Blight, A.R. Delayed Demyelination and Macrophage Invasion: A Candidate for Secondary Cell Damage in Spinal Cord Injury. Cent. Nerv. Syst. Trauma 1985, 2, 299-315. [CrossRef] [PubMed]

179. Park, Y.M.; Lee, W.T.; Bokara, K.K.; Seo, S.K.; Park, S.H.; Kim, J.H.; Yenari, M.A.; Park, K.A.; Lee, J.E. The Multifaceted Effects of Agmatine on Functional Recovery after Spinal Cord Injury through Modulations of BMP-2/4/7 Expressions in Neurons and Glial Cells. PLoS ONE 2013, 8, e53911. [CrossRef] [PubMed]

180. Setoguchi, T.; Yone, K.; Matsuoka, E.; Takenouchi, H.; Nakashima, K.; Sakou, T.; Komiya, S.; Izumo, S. Traumatic injury-induced BMP7 expression in the adult rat spinal cord. Brain Res. 2001, 921, $219-225$. [CrossRef]

181. Grinspan, J.B.; Edell, E.; Carpio, D.F.; Beesley, J.S.; Lavy, L.; Pleasure, D.; Golden, J.A. Stage-specific effects of bone morphogenetic proteins on the oligodendrocyte lineage. J. Neurobiol. 2000, 43, 1-17. [CrossRef]

182. Sabo, J.K.; Aumann, T.D.; Merlo, D.; Kilpatrick, T.J.; Cate, H.S. Remyelination Is Altered by Bone Morphogenic Protein Signaling in Demyelinated Lesions. J. Neurosci. 2011, 31, 4504-4510. [CrossRef] [PubMed] 
183. See, J.; Zhang, X.; Eraydin, N.; Golden, J.A.; Grinspan, J.B. Oligodendrocyte maturation is inhibited by bone morphogenetic protein. Mol. Cell. Neurosci. 2004, 26, 481-492. [CrossRef] [PubMed]

184. Cate, H.S.; Sabo, J.K.; Merlo, D.; Kemper, D.; Aumann, T.D.; Robinson, J.; Merson, T.D.; Emery, B.; Perreau, V.M.; Kilpatrick, T.J. Modulation of bone morphogenic protein signalling alters numbers of astrocytes and oligodendroglia in the subventricular zone during cuprizone-induced demyelination. J. Neurochem. 2010, 115, 11-22. [CrossRef] [PubMed]

185. González-Fernández, C.; Fernández-Martos, C.M.; Shields, S.D.; Arenas, E.; Javier Rodríguez, F. Wnts are expressed in the spinal cord of adult mice and are differentially induced after injury. J. Neurotrauma 2014, 31, 565-581. [CrossRef] [PubMed]

186. Fernández-Martos, C.M.; González-Fernández, C.; González, P.; Maqueda, A.; Arenas, E.; Rodríguez, F.J. Differential expression of Wnts after spinal cord contusion injury in adult rats. PLoS ONE 2011, 6, e27000. [CrossRef] [PubMed]

187. Rodriguez, J.P.; Coulter, M.; Miotke, J.; Meyer, R.L.; Takemaru, K.-I.; Levine, J.M. Abrogation of $\beta$-catenin signaling in oligodendrocyte precursor cells reduces glial scarring and promotes axon regeneration after CNS injury. J. Neurosci. 2014, 34, 10285-10297. [CrossRef] [PubMed]

188. Yao, Z.-F.; Wang, Y.; Lin, Y.-H.; Wu, Y.; Zhu, A.-Y.; Wang, R.; Shen, L.; Xi, J.; Qi, Q.; Jiang, Z.-Q.; Lü, H.-Z.; $\mathrm{Hu}, \mathrm{J} .-\mathrm{G}$. Transplantation of PDGF-AA-Overexpressing Oligodendrocyte Precursor Cells Promotes Recovery in Rat Following Spinal Cord Injury. Front. Cell. Neurosci. 2017, 11, 79. [CrossRef] [PubMed]

189. Tripathi, A.; Parikh, Z.S.; Vora, P.; Frost, E.E.; Pillai, P.P. pERK1/2 Peripheral Recruitment and Filopodia Protrusion Augment Oligodendrocyte Progenitor Cell Migration: Combined Effects of PDGF-A and Fibronectin. Cell. Mol. Neurobiol. 2017, 37, 183-194. [CrossRef] [PubMed]

190. Yang, J.; Cheng, X.; Qi, J.; Xie, B.; Zhao, X.; Zheng, K.; Zhang, Z.; Qiu, M. EGF Enhances Oligodendrogenesis from Glial Progenitor Cells. Front. Mol. Neurosci. 2017, 10, 106. [CrossRef] [PubMed]

191. Tripathi, R.B.; McTigue, D.M. Chronically increased ciliary neurotrophic factor and fibroblast growth factor-2 expression after spinal contusion in rats. J. Comp. Neurol. 2008. [CrossRef] [PubMed]

192. Louis, J.C.; Magal, E.; Takayama, S.; Varon, S. CNTF protection of oligodendrocytes against natural and tumor necrosis factor-induced death. Science 1993, 259, 689-692. [CrossRef] [PubMed]

193. Oyesiku, N.M.; Wilcox, J.N.; Wigston, D.J. Changes in expression of ciliary neurotrophic factor (CNTF) and CNTF-receptor alpha after spinal cord injury. J. Neurobiol. 1997, 32, 251-261. [CrossRef]

194. Oyesiku, N.M.; Evans, C.-O.; Houston, S.; Darrell, R.S.; Smith, J.S.; Fulop, Z.L.; Dixon, C.E.; Stein, D.G. Regional changes in the expression of neurotrophic factors and their receptors following acute traumatic brain injury in the adult rat brain. Brain Res. 1999, 833, 161-172. [CrossRef]

195. Cao, Q.; He, Q.; Wang, Y.; Cheng, X.; Howard, R.M.; Zhang, Y.; DeVries, W.H.; Shields, C.B.; Magnuson, D.S.K.; $\mathrm{Xu}, \mathrm{X} . \mathrm{M}$.; et al. Transplantation of ciliary neurotrophic factor-expressing adult oligodendrocyte precursor cells promotes remyelination and functional recovery after spinal cord injury. J. Neurosci. 2010, 30, 2989-3001. [CrossRef] [PubMed]

196. McTigue, D.M.; Horner, P.J.; Stokes, B.T.; Gage, F.H. Neurotrophin-3 and brain-derived neurotrophic factor induce oligodendrocyte proliferation and myelination of regenerating axons in the contused adult rat spinal cord. J. Neurosci. 1998, 18, 5354-5365. [CrossRef] [PubMed]

197. Xu, X.M.; Guénard, V.; Kleitman, N.; Aebischer, P.; Bunge, M.B. A Combination of BDNF and NT-3 Promotes Supraspinal Axonal Regeneration into Schwann Cell Grafts in Adult Rat Thoracic Spinal Cord. Exp. Neurol. 1995, 134, 261-272. [CrossRef] [PubMed]

198. Thomas, A.M.; Seidlits, S.K.; Goodman, A.G.; Kukushliev, T.V.; Hassani, D.M.; Cummings, B.J.; Anderson, A.J.; Shea, L.D. Sonic hedgehog and neurotrophin-3 increase oligodendrocyte numbers and myelination after spinal cord injury. Integr. Biol. (Camb). 2014, 6, 694-705. [CrossRef] [PubMed]

199. McCreedy, D.A.; Wilems, T.S.; Xu, H.; Butts, J.C.; Brown, C.R.; Smith, A.W.; Sakiyama-Elbert, S.E. Survival, Differentiation, and Migration of High-Purity Mouse Embryonic Stem Cell-derived Progenitor Motor Neurons in Fibrin Scaffolds after Sub-Acute Spinal Cord Injury. Biomater. Sci. 2014, 2, 1672-1682. [CrossRef] [PubMed]

200. Bartholdi, D.; Schwab, M.E. Oligodendroglial reaction following spinal cord injury in rat: transient upregulation of MBP mRNA. Glia 1998, 23, 278-284. [CrossRef] 
201. Dougherty, K.D.; Dreyfus, C.F.; Black, I.B. Brain-Derived Neurotrophic Factor in Astrocytes, Oligodendrocytes, and Microglia/Macrophages after Spinal Cord Injury. Neurobiol. Dis. 2000, 7, 574-585. [CrossRef] [PubMed]

202. Ikeda, O.; Murakami, M.; Ino, H.; Yamazaki, M.; Nemoto, T.; Koda, M.; Nakayama, C.; Moriya, H. Acute up-regulation of brain-derived neurotrophic factor expression resulting from experimentally induced injury in the rat spinal cord. Acta Neuropathol. 2001, 102, 239-245. [CrossRef] [PubMed]

203. Ikeda, O.; Murakami, M.; Ino, H.; Yamazaki, M.; Koda, M.; Nakayama, C.; Moriya, H. Effects of Brain-Derived Neurotrophic Factor (BDNF) on Compression-Induced Spinal Cord Injury: BDNF Attenuates Down-Regulation of Superoxide Dismutase Expression and Promotes Up-Regulation of Myelin Basic Protein Expression. J. Neuropathol. Exp. Neurol. 2002, 61, 142-153. [CrossRef] [PubMed]

204. Zhao, J.; Sun, W.; Cho, H.M.; Ouyang, H.; Li, W.; Lin, Y.; Do, J.; Zhang, L.; Ding, S.; Liu, Y.; et al. Integration and long distance axonal regeneration in the central nervous system from transplanted primitive neural stem cells. J. Biol. Chem. 2013, 288, 164-168. [CrossRef] [PubMed]

205. Sharma, H.S.; Nyberg, F.; Westman, J.; Alm, P.; Gordh, T.; Lindholm, D. Brain derived neurotrophic factor and insulin like growth factor-1 attenuate upregulation of nitric oxide synthase and cell injury following trauma to the spinal cord. Amino Acids 1998, 14, 121-129. [CrossRef] [PubMed]

206. Kwak, E.K.; Kim, J.W.; Kang, K.S.; Lee, Y.H.; Hua, Q.H.; Park, T.I.; Park, J.Y.; Sohn, Y.K. The Role of Inducible Nitric Oxide Synthase Following Spinal Cord Injury in Rat. J. Korean Med. Sci. 2005, 20, 663. [CrossRef] [PubMed]

207. Thorburne, S.K.; Juurlink, B.H. Low glutathione and high iron govern the susceptibility of oligodendroglial precursors to oxidative stress. J. Neurochem. 1996, 67, 1014-1022. [CrossRef] [PubMed]

208. Li, L.; Xu, Q.; Wu, Y.; Hu, W.; Gu, P.; Fu, Z. Combined therapy of methylprednisolone and brain-derived neurotrophic factor promotes axonal regeneration and functional recovery after spinal cord injury in rats. Chin. Med. J. (Engl). 2003, 116, 414-418. [PubMed]

209. Hu, J.-G.; Shen, L.; Wang, R.; Wang, Q.-Y.; Zhang, C.; Xi, J.; Ma, S.-F.; Zhou, J.-S.; Lü, H.-Z. Effects of Olig2-overexpressing neural stem cells and myelin basic protein-activated T cells on recovery from spinal cord injury. Neurotherapeutics 2012, 9, 422-445. [CrossRef] [PubMed]

210. Ramos-Cejudo, J.; Gutierrez-Fernandez, M.; Otero-Ortega, L.; Rodriguez-Frutos, B.; Fuentes, B.; Vallejo-Cremades, M.T.; Hernanz, T.N.; Cerdan, S.; Diez-Tejedor, E. Brain-Derived Neurotrophic Factor Administration Mediated Oligodendrocyte Differentiation and Myelin Formation in Subcortical Ischemic Stroke. Stroke 2015, 46, 221-228. [CrossRef] [PubMed]

211. Kataria, H.; Alizadeh, A.; Shahriary, G.M.; Saboktakin Rizi, S.; Henrie, R.; Santhosh, K.T.; Thliveris, J.A.; Karimi-Abdolrezaee, $\mathrm{S}$. Neuregulin-1 promotes remyelination and fosters a pro-regenerative inflammatory response in focal demyelinating lesions of the spinal cord. Glia 2018, 66, 538-561. [CrossRef] [PubMed]

212. Bartus, K.; Galino, J.; James, N.D.; Hernandez-Miranda, L.R.; Dawes, J.M.; Fricker, F.R.; Garratt, A.N.; McMahon, S.B.; Ramer, M.S.; Birchmeier, C.; et al. Neuregulin-1 controls an endogenous repair mechanism after spinal cord injury. Brain 2016, 139, 1394-1416. [CrossRef] [PubMed]

213. Alizadeh, A.; Karimi-Abdolrezaee, S. Microenvironmental regulation of oligodendrocyte replacement and remyelination in spinal cord injury. J. Physiol. 2016, 594, 3539-3552. [CrossRef] [PubMed]

214. Cheville, A.L.; Kirshblum, S.C. Thyroid hormone changes in chronic spinal cord injury. J. Spinal Cord Med. 1995, 18, 227-232. [CrossRef] [PubMed]

215. Bugaresti, J.M.; Tator, C.H.; Silverberg, J.D.; Szalai, J.P.; Malkin, D.G.; Malkin, A.; Tay, S.K. Changes in thyroid hormones, thyroid stimulating hormone and cortisol in acute spinal cord injury. Spinal Cord 1992, 30, 401-409. [CrossRef] [PubMed]

216. Shultz, R.B.; Wang, Z.; Nong, J.; Zhang, Z.; Zhong, Y. Local delivery of thyroid hormone enhances oligodendrogenesis and myelination after spinal cord injury. J. Neural Eng. 2017, 14, 36014. [CrossRef] [PubMed]

217. Annunziata, M.; Granata, R.; Ghigo, E. The IGF system. Acta Diabetol. 2011, 48, 1-9. [CrossRef] [PubMed]

218. Garcia-Estrada, J.; Garcia-Segura, L.M.; Torres-Aleman, I. Expression of insulin-like growth factor I by astrocytes in response to injury. Brain Res. 1992, 592, 343-347. [CrossRef]

219. O’Donnell, S.L.; Frederick, T.J.; Krady, J.K.; Vannucci, S.J.; Wood, T.L. IGF-I and microglia/macrophage proliferation in the ischemic mouse brain. Glia 2002, 39, 85-97. [CrossRef] [PubMed] 
220. Latov, N.; Nilaver, G.; Zimmerman, E.A.; Johnson, W.G.; Silverman, A.J.; Defendini, R.; Cote, L. Fibrillary astrocytes proliferate in response to brain injury: a study combining immunoperoxidase technique for glial fibrillary acidic protein and radioautography of tritiated thymidine. Dev. Biol. 1979, 72, 381-384. [CrossRef]

221. Dusart, I.; Schwab, M.E. Secondary cell death and the inflammatory reaction after dorsal hemisection of the rat spinal cord. Eur. J. Neurosci. 1994, 6, 712-724. [CrossRef] [PubMed]

222. Hinks, G.L.; Franklin, R.J.M. Distinctive Patterns of PDGF-A, FGF-2, IGF-I, and TGF- $\beta 1$ Gene Expression during Remyelination of Experimentally-Induced Spinal Cord Demyelination. Mol. Cell. Neurosci. 1999, 14, 153-168. [CrossRef] [PubMed]

223. Yao, D.-L.; West, N.R.; Bondy, C.A.; Brenner, M.; Hudson, L.D.; Zhou, J.; Collins, G.H.; Webster, H.D. Cryogenic spinal cord injury induces astrocytic gene expression of insulin-like growth factor I and insulin-like growth factor binding protein 2 during myelin regeneration. J. Neurosci. Res. 1995, 40, 647-659. [CrossRef] [PubMed]

224. Kazanis, I.; Giannakopoulou, M.; Philippidis, H.; Stylianopoulou, F. Alterations in IGF-I, BDNF and NT-3 levels following experimental brain trauma and the effect of IGF-I administration. Exp. Neurol. 2004, 186, 221-234. [CrossRef] [PubMed]

225. Moghaddam, A.; Sperl, A.; Heller, R.; Kunzmann, K.; Graeser, V.; Akbar, M.; Gerner, H.J.; Biglari, B. Elevated Serum Insulin-Like Growth Factor 1 Levels in Patients with Neurological Remission after Traumatic Spinal Cord Injury. PLoS ONE 2016, 11, e0159764. [CrossRef] [PubMed]

226. Feeney, C.; Sharp, D.J.; Hellyer, P.J.; Jolly, A.E.; Cole, J.H.; Scott, G.; Baxter, D.; Jilka, S.; Ross, E.; Ham, T.E.; et al. Serum insulin-like growth factor-I levels are associated with improved white matter recovery after traumatic brain injury. Ann. Neurol. 2017, 82, 30-43. [CrossRef] [PubMed]

227. Thomas, A.J.; Nockels, R.P.; Pan, H.Q.; Shaffrey, C.I.; Chopp, M. Progesterone is Neuroprotective After Acute Experimental Spinal Cord Trauma in Rats. Spine (Phila. Pa. 1976). 1999, 24, 2134. [CrossRef]

228. Labombarda, F.; González, S.L.; Lima, A.; Roig, P.; Guennoun, R.; Schumacher, M.; de Nicola, A.F. Effects of progesterone on oligodendrocyte progenitors, oligodendrocyte transcription factors, and myelin proteins following spinal cord injury. Glia 2009, 57, 884-897. [CrossRef] [PubMed]

229. Zhou, Q.; Choi, G.; Anderson, D.J. The bHLH transcription factor Olig2 promotes oligodendrocyte differentiation in collaboration with Nkx2.2. Neuron 2001, 31, 791-807. [CrossRef]

230. Arnett, H.A.; Fancy, S.P.J.; Alberta, J.A.; Zhao, C.; Plant, S.R.; Kaing, S.; Raine, C.S.; Rowitch, D.H.; Franklin, R.J.M.; Stiles, C.D. bHLH Transcription Factor Olig1 Is Required to Repair Demyelinated Lesions in the CNS. Science 2004, 306, 2111-2115. [CrossRef] [PubMed]

231. Galani, R.; Hoffman, S.W.; Stein, D.G. Effects of the duration of progesterone treatment on the resolution of cerebral edema induced by cortical contusions in rats. Restor. Neurol. Neurosci. 2001, 18, 161-166. [PubMed]

232. Cutler, S.M.; Cekic, M.; Miller, D.M.; Wali, B.; VanLandingham, J.W.; Stein, D.G. Progesterone Improves Acute Recovery after Traumatic Brain Injury in the Aged Rat. J. Neurotrauma 2007, 24, 1475-1486. [CrossRef] [PubMed]

233. Fawcett, J.W.; Asher, R.A. The glial scar and central nervous system repair. Brain Res. Bull. 1999, 49, $377-391$. [CrossRef]

234. Siebert, J.R.; Osterhout, D.J. The inhibitory effects of chondroitin sulfate proteoglycans on oligodendrocytes. J. Neurochem. 2011, 119, 176-188. [CrossRef] [PubMed]

235. Pendleton, J.C.; Shamblott, M.J.; Gary, D.S.; Belegu, V.; Hurtado, A.; Malone, M.L.; McDonald, J.W. Chondroitin sulfate proteoglycans inhibit oligodendrocyte myelination through PTPo. Exp. Neurol. 2013, 247, 113-121. [CrossRef] [PubMed]

236. Jahan, N.; Hannila, S.S. Transforming growth factor $\beta$-induced expression of chondroitin sulfate proteoglycans is mediated through non-Smad signaling pathways. Exp. Neurol. 2015, 263, 372-384. [CrossRef] [PubMed]

237. Schachtrup, C.; Ryu, J.K.; Helmrick, M.J.; Vagena, E.; Galanakis, D.K.; Degen, J.L.; Margolis, R.U.; Akassoglou, K. Fibrinogen triggers astrocyte scar formation by promoting the availability of active TGF-beta after vascular damage. J. Neurosci. 2010, 30, 5843-5854. [CrossRef] [PubMed]

238. Susarla, B.T.S.; Laing, E.D.; Yu, P.; Katagiri, Y.; Geller, H.M.; Symes, A.J. Smad proteins differentially regulate transforming growth factor- $\beta$-mediated induction of chondroitin sulfate proteoglycans. J. Neurochem. 2011, 119, 868-878. [CrossRef] [PubMed] 
239. Lau, L.W.; Keough, M.B.; Haylock-Jacobs, S.; Cua, R.; Döring, A.; Sloka, S.; Stirling, D.P.; Rivest, S.; Yong, V.W. Chondroitin sulfate proteoglycans in demyelinated lesions impair remyelination. Ann. Neurol. 2012, 72, 419-432. [CrossRef] [PubMed]

240. Karimi-Abdolrezaee, S.; Eftekharpour, E.; Wang, J.; Schut, D.; Fehlings, M.G. Synergistic Effects of Transplanted Adult Neural Stem/Progenitor Cells, Chondroitinase, and Growth Factors Promote Functional Repair and Plasticity of the Chronically Injured Spinal Cord. J. Neurosci. 2010, 30, 1657-1676. [CrossRef] [PubMed]

241. Siebert, J.R.; Stelzner, D.J.; Osterhout, D.J. Chondroitinase treatment following spinal contusion injury increases migration of oligodendrocyte progenitor cells. Exp. Neurol. 2011, 231, 19-29. [CrossRef] [PubMed]

242. Hammond, T.R.; Gadea, A.; Dupree, J.; Kerninon, C.; Nait-Oumesmar, B.; Aguirre, A.; Gallo, V. AstrocyteDerived Endothelin-1 Inhibits Remyelination through Notch Activation. Neuron 2014, 81, 588-602. [CrossRef] [PubMed]

243. Domingues, H.S.; Portugal, C.C.; Socodato, R.; Relvas, J.B. Oligodendrocyte, Astrocyte, and Microglia Crosstalk in Myelin Development, Damage, and Repair. Front. cell Dev. Biol. 2016, 4, 71. [CrossRef] [PubMed]

244. Wang, H.-F.; Liu, X.-K.; Li, R.; Zhang, P.; Chu, Z.; Wang, C.-L.; Liu, H.-R.; Qi, J.; Lv, G.-Y.; Wang, G.-Y.; et al. Effect of glial cells on remyelination after spinal cord injury. Neural Regen. Res. 2017, 12, 1724-1732. [CrossRef] [PubMed]

245. Arnett, H.A.; Mason, J.; Marino, M.; Suzuki, K.; Matsushima, G.K.; Ting, J.P.-Y. TNF $\alpha$ promotes proliferation of oligodendrocyte progenitors and remyelination. Nat. Neurosci. 2001, 4, 1116-1122. [CrossRef] [PubMed]

246. Vela, J.M.; Molina-Holgado, E.; Arévalo-Martín, Á.; Almazán, G.; Guaza, C. Interleukin-1 Regulates Proliferation and Differentiation of Oligodendrocyte Progenitor Cells. Mol. Cell. Neurosci. 2002, 20, 489-502. [CrossRef] [PubMed]

247. Schulz, K.; Kroner, A.; David, S. Iron efflux from astrocytes plays a role in remyelination. J. Neurosci. 2012, 32, 4841-4847. [CrossRef] [PubMed]

248. Kıray, H.; Lindsay, S.L.; Hosseinzadeh, S.; Barnett, S.C. The multifaceted role of astrocytes in regulating myelination. Exp. Neurol. 2016, 283, 541-549. [CrossRef]

249. Tripathi, R.; McTigue, D.M. Prominent oligodendrocyte genesis along the border of spinal contusion lesions. Glia 2007. [CrossRef] [PubMed]

250. Almad, A.; McTigue, D.M. Chronic expression of PPAR- $\delta$ by oligodendrocyte lineage cells in the injured rat spinal cord. J. Comp. Neurol. 2010, 518, 785-799. [CrossRef] [PubMed]

251. Hesp, Z.C.; Yoseph, R.Y.; Suzuki, R.; Jukkola, P.; Wilson, C.; Nishiyama, A.; McTigue, D.M. Proliferating NG2-Cell-Dependent Angiogenesis and Scar Formation Alter Axon Growth and Functional Recovery After Spinal Cord Injury in Mice. J. Neurosci. 2018, 38, 1366-1382. [CrossRef] [PubMed]

252. Moyon, S.; Dubessy, A.L.; Aigrot, M.S.; Trotter, M.; Huang, J.K.; Dauphinot, L.; Potier, M.C.; Kerninon, C.; Melik Parsadaniantz, S.; Franklin, R.J.M.; et al. Demyelination Causes Adult CNS Progenitors to Revert to an Immature State and Express Immune Cues That Support Their Migration. J. Neurosci. 2015, 35, 4-20. [CrossRef] [PubMed]

253. Gensel, J.C.; Zhang, B. Macrophage activation and its role in repair and pathology after spinal cord injury. Brain Res. 2015, 1619, 1-11. [CrossRef] [PubMed]

254. Levine, J. The reactions and role of NG2 glia in spinal cord injury. Brain Res. 2016, 1638, 199-208. [CrossRef] [PubMed]

255. Goldstein, E.Z.; Church, J.S.; Hesp, Z.C.; Popovich, P.G.; McTigue, D.M. A silver lining of neuroinflammation: Beneficial effects on myelination. Exp. Neurol. 2016. [CrossRef] [PubMed]

256. Setzu, A.; Lathia, J.D.; Zhao, C.; Wells, K.; Rao, M.S.; Ffrench-Constant, C.; Franklin, R.J.M. Inflammation stimulates myelination by transplanted oligodendrocyte precursor cells. Glia 2006, 54, 297-303. [CrossRef] [PubMed]

257. Miron, V.E.; Boyd, A.; Zhao, J.-W.; Yuen, T.J.; Ruckh, J.M.; Shadrach, J.L.; van Wijngaarden, P.; Wagers, A.J.; Williams, A.; Franklin, R.J.M.; et al. M2 microglia and macrophages drive oligodendrocyte differentiation during CNS remyelination. Nat. Neurosci. 2013, 16, 1211-1218. [CrossRef] [PubMed]

258. Kigerl, K.A.; Gensel, J.C.; Ankeny, D.P.; Alexander, J.K.; Donnelly, D.J.; Popovich, P.G. Identification of two distinct macrophage subsets with divergent effects causing either neurotoxicity or regeneration in the injured mouse spinal cord. J. Neurosci. 2009, 29, 13435-13444. [CrossRef] [PubMed] 
259. Azari, M.F.; Profyris, C.; Karnezis, T.; Bernard, C.C.; Small, D.H.; Cheema, S.S.; Ozturk, E.; Hatzinisiriou, I.; Petratos, S. Leukemia Inhibitory Factor Arrests Oligodendrocyte Death and Demyelination in Spinal Cord Injury. J. Neuropathol. Exp. Neurol. 2006, 65, 914-929. [CrossRef] [PubMed]

260. Kerr, B.J.; Patterson, P.H. Leukemia inhibitory factor promotes oligodendrocyte survival after spinal cord injury. Glia 2005, 51, 73-79. [CrossRef] [PubMed]

261. Zang, D.W.; Cheema, S.S. Leukemia Inhibitory Factor Promotes Recovery of Locomotor Function following Spinal Cord Injury in the Mouse. J. Neurotrauma 2003, 20, 1215-1222. [CrossRef] [PubMed]

262. Rittchen, S.; Boyd, A.; Burns, A.; Park, J.; Fahmy, T.M.; Metcalfe, S.; Williams, A. Myelin repair in vivo is increased by targeting oligodendrocyte precursor cells with nanoparticles encapsulating leukaemia inhibitory factor (LIF). Biomaterials 2015, 56, 78-85. [CrossRef] [PubMed]

263. Letterio, J.J.; Roberts, A.B. REGULATION OF IMMUNE RESPONSES BY TGF- $\beta$. Annu. Rev. Immunol. 1998, 16, 137-161. [CrossRef] [PubMed]

264. McTigue, D.M.; Popovich, P.G.; Morgan, T.E.; Stokes, B.T. Localization of Transforming Growth Factor- $\beta 1$ and Receptor mRNA after Experimental Spinal Cord Injury. Exp. Neurol. 2000, 163, 220-230. [CrossRef] [PubMed]

265. Hellal, F.; Hurtado, A.; Ruschel, J.; Flynn, K.C.; Laskowski, C.J.; Umlauf, M.; Kapitein, L.C.; Strikis, D.; Lemmon, V.; Bixby, J.; et al. Microtubule stabilization reduces scarring and causes axon regeneration after spinal cord injury. Science 2011, 331, 928-931. [CrossRef] [PubMed]

266. Kohta, M.; Kohmura, E.; Yamashita, T. Inhibition of TGF- $\beta 1$ promotes functional recovery after spinal cord injury. Neurosci. Res. 2009, 65, 393-401. [CrossRef] [PubMed]

267. Miron, V.E. Microglia-driven regulation of oligodendrocyte lineage cells, myelination, and remyelination. J. Leukoc. Biol. 2017, 101, 1103-1108. [CrossRef] [PubMed]

268. Schonberg, D.L.; Popovich, P.G.; McTigue, D.M. Oligodendrocyte Generation Is Differentially Influenced by Toll-Like Receptor (TLR) 2 and TLR4-Mediated Intraspinal Macrophage Activation. J. Neuropathol. Exp. Neurol. 2007, 66, 1124-1135. [CrossRef] [PubMed]

269. Goldstein, E.Z.; Church, J.S.; Pukos, N.; Gottipati, M.K.; Popovich, P.G.; McTigue, D.M. Intraspinal TLR4 activation promotes iron storage but does not protect neurons or oligodendrocytes from progressive iron-mediated damage. Exp. Neurol. 2017, 298, 42-56. [CrossRef] [PubMed]

270. Schonberg, D.L.; McTigue, D.M. Iron is essential for oligodendrocyte genesis following intraspinal macrophage activation. Exp. Neurol. 2009. [CrossRef] [PubMed]

271. Schonberg, D.L.; Goldstein, E.Z.; Sahinkaya, F.R.; Wei, P.; Popovich, P.G.; McTigue, D.M. Ferritin Stimulates Oligodendrocyte Genesis in the Adult Spinal Cord and Can Be Transferred from Macrophages to NG2 Cells In Vivo. J. Neurosci. 2012, 32, 5374-5384. [CrossRef] [PubMed]

272. Kigerl, K.A.; Lai, W.; Rivest, S.; Hart, R.P.; Satoskar, A.R.; Popovich, P.G. Toll-like receptor (TLR)-2 and TLR-4 regulate inflammation, gliosis, and myelin sparing after spinal cord injury. J. Neurochem. 2007, 102, 37-50. [CrossRef] [PubMed]

273. Church, J.S.; Kigerl, K.A.; Lerch, J.K.; Popovich, P.G.; McTigue, D.M. TLR4 Deficiency Impairs Oligodendrocyte Formation in the Injured Spinal Cord. J. Neurosci. 2016, 36, 6352-6364. [CrossRef] [PubMed]

274. Sauerbeck, A.; Schonberg, D.L.; Laws, J.L.; McTigue, D.M. Systemic iron chelation results in limited functional and histological recovery after traumatic spinal cord injury in rats. Exp. Neurol. 2013. [CrossRef] [PubMed]

275. Sahinkaya, F.R.; Milich, L.M.; McTigue, D.M. Changes in NG2 cells and oligodendrocytes in a new model of intraspinal hemorrhage. Exp. Neurol. 2014. [CrossRef] [PubMed]

276. Rathore, K.I.; Kerr, B.J.; Redensek, A.; López-Vales, R.; Jeong, S.Y.; Ponka, P.; David, S. Ceruloplasmin protects injured spinal cord from iron-mediated oxidative damage. J. Neurosci. 2008, 28, 12736-12747. [CrossRef] [PubMed]

277. Yoshimura, A.; Naka, T.; Kubo, M. SOCS proteins, cytokine signalling and immune regulation. Nat. Rev. Immunol. 2007, 7, 454-465. [CrossRef] [PubMed]

278. Schmitz, J.; Weissenbach, M.; Haan, S.; Heinrich, P.C.; Schaper, F. SOCS3 exerts its inhibitory function on interleukin-6 signal transduction through the SHP2 recruitment site of gp130. J. Biol. Chem. 2000, 275, 12848-12856. [CrossRef] [PubMed]

279. Park, K.W.; Lin, C.-Y.; Li, K.; Lee, Y.-S. Effects of Reducing Suppressors of Cytokine Signaling-3 (SOCS3) Expression on Dendritic Outgrowth and Demyelination after Spinal Cord Injury. PLoS ONE 2015, 10, e0138301. [CrossRef] [PubMed] 
280. Yoshimura, A.; Suzuki, M.; Sakaguchi, R.; Hanada, T.; Yasukawa, H. SOCS, Inflammation, and Autoimmunity. Front. Immunol. 2012, 3, 20. [CrossRef] [PubMed]

281. Whyte, C.S.; Bishop, E.T.; Rückerl, D.; Gaspar-Pereira, S.; Barker, R.N.; Allen, J.E.; Rees, A.J.; Wilson, H.M. Suppressor of cytokine signaling ( SOCS ) 1 is a key determinant of differential macrophage activation and function. J. Leukoc. Biol 2011, 90, 845-854. [CrossRef] [PubMed]

282. Kerr, B.J.; Girolami, E.I.; Ghasemlou, N.; Jeong, S.Y.; David, S. The protective effects of 15-deoxy- $\Delta-$ 12,14-prostaglandin $\mathrm{J} 2$ in spinal cord injury. Glia 2008, 56, 436-448. [CrossRef] [PubMed]

283. Arnold, C.E.; Whyte, C.S.; Gordon, P.; Barker, R.N.; Rees, A.J.; Wilson, H.M. A critical role for suppressor of cytokine signalling 3 in promoting M1 macrophage activation and function in vitro and in vivo. Immunology 2014, 141, 96-110. [CrossRef] [PubMed]

284. Okada, S.; Nakamura, M.; Katoh, H.; Miyao, T.; Shimazaki, T.; Ishii, K.; Yamane, J.; Yoshimura, A.; Iwamoto, Y.; Toyama, Y.; et al. Conditional ablation of Stat3 or Socs3 discloses a dual role for reactive astrocytes after spinal cord injury. Nat. Med. 2006, 12, 829-834. [CrossRef] [PubMed]

285. Hackett, A.R.; Lee, J.K. Understanding the NG2 Glial Scar after Spinal Cord Injury. Front. Neurol. 2016, 7, 199. [CrossRef] [PubMed]

286. Donnelly, D.J.; Longbrake, E.E.; Shawler, T.M.; Kigerl, K.A.; Lai, W.; Tovar, C.A.; Ransohoff, R.M.; Popovich, P.G. Deficient CX3CR1 signaling promotes recovery after mouse spinal cord injury by limiting the recruitment and activation of Ly6Clo/iNOS+ macrophages. J. Neurosci. 2011, 31, 9910-9922. [CrossRef] [PubMed]

287. Freria, C.M.; Hall, J.C.E.; Wei, P.; Guan, Z.; McTigue, D.M.; Popovich, P.G. Deletion of the Fractalkine Receptor, CX3CR1, Improves Endogenous Repair, Axon Sprouting, and Synaptogenesis after Spinal Cord Injury in Mice. J. Neurosci. 2017, 37, 3568-3587. [CrossRef] [PubMed]

288. Patel, J.R.; McCandless, E.E.; Dorsey, D.; Klein, R.S. CXCR4 promotes differentiation of oligodendrocyte progenitors and remyelination. Proc. Natl. Acad. Sci. USA 2010, 107, 11062-11067. [CrossRef] [PubMed]

289. Jaerve, A.; Müller, H.W. Chemokines in CNS injury and repair. Cell Tissue Res. 2012, 349, 229-248. [CrossRef] [PubMed]

290. Patel, J.R.; Williams, J.L.; Muccigrosso, M.M.; Liu, L.; Sun, T.; Rubin, J.B.; Klein, R.S. Astrocyte TNFR2 is required for CXCL12-mediated regulation of oligodendrocyte progenitor proliferation and differentiation within the adult CNS. Acta Neuropathol. 2012, 124, 847-860. [CrossRef] [PubMed]

291. Tirotta, E.; Kirby, L.A.; Hatch, M.N.; Lane, T.E. IFN- $\gamma$-induced apoptosis of human embryonic stem cell derived oligodendrocyte progenitor cells is restricted by CXCR2 signaling. Stem Cell Res. 2012, 9, $208-217$. [CrossRef] [PubMed]

292. Omari, K.M.; Lutz, S.E.; Santambrogio, L.; Lira, S.A.; Raine, C.S. Neuroprotection and Remyelination after Autoimmune Demyelination in Mice that Inducibly Overexpress CXCL1. Am. J. Pathol. 2009, 174, 164-176. [CrossRef] [PubMed]

293. Filipovic, R.; Zecevic, N. The effect of CXCL1 on human fetal oligodendrocyte progenitor cells. Glia 2008, 56, 1-15. [CrossRef] [PubMed]

294. Omari, K.M.; John, G.R.; Sealfon, S.C.; Raine, C.S. CXC chemokine receptors on human oligodendrocytes: implications for multiple sclerosis. Brain 2005, 128, 1003-1015. [CrossRef] [PubMed]

295. Omari, K.M.; John, G.; Lango, R.; Raine, C.S. Role for CXCR2 and CXCL1 on glia in multiple sclerosis. Glia 2006, 53, 24-31. [CrossRef] [PubMed]

296. Niu, W.; Zeng, X. The Application of Stem Cell Based Tissue Engineering in Spinal Cord Injury Repair. J. Tissue Sci. Eng. 2015, 6. [CrossRef]

297. Duncan, G.J.; Plemel, J.R.; Assinck, P.; Manesh, S.B.; Muir, F.G.W.; Hirata, R.; Berson, M.; Liu, J.; Wegner, M.; Emery, B.; et al. Myelin regulatory factor drives remyelination in multiple sclerosis. Acta Neuropathol. 2017, 134, 403-422. [CrossRef] [PubMed]

(C) 2018 by the authors. Licensee MDPI, Basel, Switzerland. This article is an open access article distributed under the terms and conditions of the Creative Commons Attribution (CC BY) license (http:/ / creativecommons.org/licenses/by/4.0/). 